\title{
JOSÉ MARTÍ EN EL EJE DE LA MODERNIZACIÓN POÉTICA: WHITMAN, LAUTRÉAMONT, RIMBAUD
}

\section{RESPUESTAS AL INTERNACIONALISMO MODERNIZADOR}

La modernización de Occidente, aunque venía de antigua data, alcanza su expresión universal en la segunda mitad del XIX, cuando los imperios centrales europeos cumplen la conquista, militar, o económica, del planeta. Ciudades como Londres, Amsterdan, Berlín rigieron ese proceso, pero cupo a París duplicarlo con una omnímoda irradiación cultural.

No sólo América Latina se arrojó al regazo de la cultura parisina. El francesismo, como gustó decir Justo Sierra, el galicismo mental, como prefirió Juan Valera, fue la marca universal en la segunda del XIX, cuando París se constituyó en la "capital cultural del Siglo", tal como la definió Walter Benjamin. Las demás capitales, incluso Londres que se había expandido culturalmente antes, mostraron atención máxima por los productos "made in France", no desdeñando algunas la franca imitación. Si eso ocurría en las metrópolis, puede inferirse con cuanta más fuerza se ejecutaría en las colonias o en los países recientemente independizados.

Ese fue el descubrimiento que hizo el "very fresh spaniard" José Martí, cuando desembarcó en New York en 1880, sorprendido de que una libre y pujante urbe viviera en estrecha dependencia del gusto francés y aun de las atracciones exóticas que tanto París como Londres habían puesto en circulación dentro de Occidente:

Libertad en la política, en las costumbres, en las empresas; humilde servilismo en los gustos. Los franceses dicen la palabra sagrada; se buscan grandes nombres y no grandes obras. Como no hay un entendimiento fijo sobre el arte, lo más detonante es lo que más gusta. No hay placer en la dulce belleza de Helena o Galatea - el gusto está enteramente dedicado a viejas e imperfectas obras de China y Japón. Si les hubiera guiado una finalidad científica a los poseedores de tales bibelots, sería objeto de alabanza. Pero es únicamente por el censurable 
placer de poseer inmoderadamente objetos exóticos comprados a alto precio $(19-100)^{1}$.

Está ya aquí la crítica al "rey burgués”, que ocho años después ejercitaría Darío en $A z u l$, aunque en estas observaciones y otras de la crítica de arte que en ese mismo año escribe para The Hour, se demuestra cuánto faltaba a su educación estética, a pesar de que fuera capaz de una apreciación (más bien literaria) de la Galatea de Gustave Moreau a la que dedicaría Julián del Casal uno de los sonetos de su "museo ideal" en Nieve (1892). Pero sólo dos años después, bajo el imperio fascinador del esteticismo de Oscar Wilde, alababa "versos, vibrantes y transparentes como porcelana japonesa".

Por ese entonces Martí comprende que el imperialismo de la cultura francesa no puede combatirse encerrándose en las estrechas y arcaicas fronteras nacionales, como reclamaban los rezagados románticos o los conservadores, y mucho menos prolongando la dependencia de la cultura española, sino avanzando aún más en el internacionalismo de la hora mediante una audaz ampliación del horizonte universal de la cultura. Cuando el 9 de enero de 1882 oye en Chickering Hall la conferencia de Oscar Wilde sobre "El renacimiento inglés del arte", espléndida exposición de un espíritu libre sobre un tema del que Martí no parecía tener entonces demasiada información, reconoce la ventaja de esta apertura literaria y la extiende a una apertura filosófica:

Conocer diversas literaturas es el medio mejor de libertarse de la tirania de algunas de ellas; así como no hay manera de salvarse del riesgo de obedecer ciegamente a un sistema filosófico, sino nutrirse en todos, y ver como en todos palpita un mismo espíritu, sujeto a semejantes accidentes, cualesquiera que sean las formas de que la imaginación humana, vehemente o menguada, según los climas, haya revestido esa fe en lo inmenso y esa ansia de salir de sí, y esa noble inconformidad con ser lo que es, que generan todas las escuelas filosóficas².

La internacionalización, como vía adecuada para alcanzar la libertad y un más alto grado de soberanía intelectual, se constituiría en adelante en el principio rector de la cultura latinoamericana, sería predicada por sus más serios e informados intelectuales y obligaría a una constante lucha con los espíritus retrógrados que desde entonces desarrollarían un hipócrita discurso sobre "lo foráneo" con el cual mal encubrían la defensa de su dominación tradi-

' Las citas con números remiten a los diferentes tomos y a las páginas de la edición de Obras completas, La Habana, 1963-73, 28 volúmenes.

2 José M ARTí, Obra literaria, Caracas, 1978 (prólogo, notas y cronología de Cintio Vitier), p. 287. 
cionalista. Partiendo de la lección francesa, los renovadores procurarían compensarla con un amplio conocimiento de otras culturas, sobre todo de la inglesa y la alemana, tal como hicieron Eugenio de Hostos, Manuel González Prada o Baldomero Sanín Cano. González Prada afirmó que "no hay mejor higiene para el cerebro que emigrar a tierra extranjera o embeberse en literaturas de otras lenguas"'3 y Sanín Cano, quien fue el más agudo ensayista literario de la época, dijo categóricamente:

Es miseria intelectual esta a que nos condenan los que suponen que los suramericanos tenemos de vivir exclusivamente de España en materia de filosofía y letras. Las gentes nuevas del Nuevo Mundo tienen derecho a toda la vida del pensamiento. No hay falta de patriotismo, ni apostasía de raza en tratar de comprender lo ruso, verbigracia, y de asi milarse uno lo escandinavo. Lo que resulta no precisamente reprensible, sino lastimoso con plenitud, es llegar a Francia y no pasar de ahít.

Para Sanín Cano se cometían dos errores sucesivos en la apropiación de la cultura universal, ambos debidos a escasa información y a menor discernimiento crítico: por una parte reducirse al foco francés al sustituir el español tradicional, lo que impedía el conocimiento de los ya numerosos centros culturales que poseía el mundo, y por la otra elegir dentro del francés, y los restantes, a los artistas menores que eran por lo común los más divulgados por ios medios periodísticos y desconocer a los mayores y más originales (leer a Catulle Mendès y no a Baudelaire, es el ejemplo que utiliza). Su libertaria defensa del derecho americano a la cultura universal, habría de ser la vía fructífera por la cual se trazaría el perfil cultural de la región: al colombiano se deberá la incorporación de las literaturas nórdicas y el conocimiento de la crítica renovada de George Brandès, como a José Juan Tablada el conocimiento de la cultura japonesa y la introducción del "haikú" en la poesía de la lengua española. Ya antes, fue gracias a José Martí que se difundió la literatura norteamericana, hacia la cual se tenía en el medio intelectual latinoamericano la mayor reticencia por razones políticas, y la primera visión panorámica de la cultura vietnamita, junto a una

3 Manuel González Prada, Páginas libres. Horas de Lucha, Caracas, 1976 (prólogo y notas de Luis Alberto Sánchez), p. 178. En su primera conferencia pública en el Ateneo de Lima (1886) ya había establecido González Prada el principio de independencia cultural respecto a España: "Basados, pues, en la tradición de independencia literaria, que puede remontarse hasta los poetas ibérico-latinos como Séneca y Luciano, dejemos las andaderas de la infancia y busquemos en otras literaturas nuevos elementos y nuevas impulsiones. Al espíritu de naciones ultramontanas y monárquicas, prefiramos el espíritu libre y democrático del Siglo"' (p. 17).

${ }^{4}$ Baldomero $S_{\text {anin }}$ Cano, El oficio de lector, Caracas, s.f. (compilación, prólogo y cronología de J.G. Cobo Borda), pp. 92-93. 
curiosidad por la evolución del arte y el pensamiento rusos que puede seguirse en artículos y mejor aún en las anotaciones de sus Cuadernos de Apuntes.

Los escritores hispanoamericanos fundaron su desvío de la producción intelectual española, no en una improbable decadencia del equipo peninsular 5 , sino en lo que Justo Sierra llamó "el acueducto español" y Manuel González Prada "la aduana española", es decir, el reconocimiento de que España estaba llevando a cabo -y eso desde los afrancesados del XVIII- un trasvasamiento de la cultura francesa, adaptándola a los particulares de la tradición cultural hispana. Aceptar pasivamente esa adaptación peninsular, continuando la dependencia respecto a la cultura madre que ya no era rectora mundial, resultaba perjudicial para el espíritu independiente a que aspiraba América Latina y contradictorio con la ya adquirida capacidad de los americanos para hacer ellos mismos ese trasvasamiento, adaptando la cultura universal a las que, en la época, se podían reconocer como formas oeculiares de una cultura continental, emparentadas aunque distintas de las peninsulares.

Los hispanoamericanos leyeron los originales franceses y las adaptaciones españolas simultáneamente y concluyeron, correctamente, que era mejor remitirse a los primeros que eran los modelos. Así evitaban, además, las distorsiones que, en las segundas, imponía el conservadurismo oficialista de España. La precisa y ácida valoración de Juan Valera traductor que hizo Manuel González Prada, registrando las pintorescas acomodaciones a que sometía las Pastorales de Longo (cambiando el sexo a un personaje para no chocar a la moral de la época) y la divertida apreciación que hace de la relación amor-odio que mantenían algunos autores españoles con sus modelos franceses, fueron compartidas por la mayoría de los intelectuales modernistas:

Atacar todo lo francés achaque de todo buen español. Algunos escritores castellanos copian, imitan o traducen a Victor Hugo, y apenas acaban de hacerlo, le embisten y le denigran. Cosa muy natural: cuando un amigo nos convida la sopa, nos hartamos bien, y en seguida hablamos mal de la sopa del amigo ${ }^{6}$.

Esta curiosidad alerta, que signaría tantos libros, de letras, de sociología, de criminología, de historia, de filosofía, de religión, de ciencia (Los raros de Darío son su paradigma literario) y la forma indiscriminada, asistemática, en que se ejercería, mezclando épocas diferentes, estéticas opuestas, movimientos discordes, las más variadas culturas del planeta en un bazar disparatado, habrían de expli-

${ }^{5}$ Ya refutada por Manuel Pedro González en sus Notas en torno al modernismo, México, 1958, pp. 27-35.

${ }^{6}$ Op. cit., p. 138. 
car el curioso sincretismo que caracteriza al modernismo hispanoamericano, donde los contrarios se codean amistosamente como en un salón mundano. Tal curiosidad también habría de orientar al pensamiento hispanoamericano hacia una interpretación conjunta de las diversas aportaciones internacionales, descubriendo lo que en ellas había de concurrente bajo su aparencial divergencia, que es lo que ya señalaba Marti al referirse a los distintos sistemas filosóficos existentes. En ese texto, en sus apuntaciones para sus clases de filosofía, es notorio el sincretismo que busca unificar a los opuestos sistemas filosóficos de la época, aun a costa de forzarlos, aunque quizás haya aquí una huella de la mediocre fuente krausista en que se había educado en España.

En una instancia superior, esa misma ampliación del panorama internacional de la cultura dejaría de aplicarse a los diversos sistemas buscando una solución sincrética, para trasladarse al examen de los mecanismos psico-lógicos utilizados en los razonamientos que servían de base a esos sistemas. Se trataba del mismo traspaso que se registró en la literatura, pasando del nivel concreto y referencial al nivel diagramático abstracto (mediante uso de signossímbolos), reconstruyendo por lo tanto las operaciones intelectuales que diseñan un conjun to en vez de acantonarse en la mención de los particulares mediante esquemas asociativos convencionales. Quien realizó magistralmente esa tarea fue Carlos Vaz Ferreira en su Lógica viva (1910), libro que, para Manuel Claps, "nace de la síntesis original que realiza nuestro autor entre la nueva concepción de la vida psíquica de Williams James y Henri Bergson y el pensamiento lógico de Stuart Mill"' . El reconocimiento de tales variadas fuentes, que representan las aportaciones filosóficas de Estados Unidos, Francia e Inglaterra, nada resta a una originalidad que se alcanza mediante el cotejo crítico de los modos de pensar, más que del estudio de los discursos sistemáticos, observando sus imperfecciones por carencia de jerarquización entre sus diversos términos o por enlaces ilógicamente fundados de sus articulaciones. La primera lección del libro, sobre los "Errores de falsa oposición", comienza por una observación que sin duda hubiera complacido a Martí:

Una de las mayores adquisiciones del pensamiento se realizaría cuando los hombres comprendieran -no sólo comprendieran sino sintieranque una gran parte de las teorias, opiniones, observaciones, etc, que se tratan como opuestas, no lo son. Es una de las falacias más comunes, y por lo cual se gasta en pura pérdida la mayor parte del trabajo pensante de la humanidad, la que consiste en tomar por contradictorio lo que no es contradictorio; en crear falsos dilemas, falsas oposiciones. Dentro de esa falacia, la muy común que consiste en tomar lo complementario

7 Prólogo a Carlos Vaz Ferreira, Lógica viva, Moral para intelectuales, Caracas, 1979, p. xxi. 
por contradictorio, no es más que un caso particular de ella, pero un caso prácticamente muy importante ${ }^{8}$.

Tanto en la Lógica viva, como en la Moral para intelectuales del mismo Vaz Ferreira, alcanza maduración esta operación crítica sobre el internacionalismo cultural, la que también puede seguirse en la obra de Enrique José Varona como en la de Alejandro Korn, ya que en todos los casos sirvió de plataforma para diseñar una percepción original (no sólo por el talento de quienes la formularon, sino también por el punto excéntrico desde donde la concibieron) que sometía a examen crítico las diversas proposiciones y, sobre todo, Tas ponía en la perspectiva de una problemática propia, la de una cultura hispanoamericana suficientemente robusta como para responder a la múltiple incitación exterior con lucidez.

Que en la psico-lógica de Vaz Ferreira está actuando este sincretismo peculiar de América Latina y aún más, el eclecticismo que marcó al mundo-1900, claramente lo revela uno de sus psicogramas: "Fórmula para saludar cualquier novedad artística, escuela, tendencia o procedimiento: Bienvenido; entendiéndose que no es en lugar de nada, sino además de todo"9. Es, asimismo, revelador de la respuesta intelectual de América a la apropiación internacional que vivía, la atención que Vaz Ferreira dirige al estudio de la lengua y al análisis de la significación, pues si, para él, el pensamiento lógico no es sino un esquema superpuesto a la fluidez del psiquismo, a su vez el lenguaje es un segundo esquema aferrado al esquema de la lógica, con lo cual se habría desvirtuado en dos niveles sucesivos a la realidad mental, siendo ésta, - la verdadera, la auténtica - la que debería recogerse en el discurso intelectual. Esta pesquisa de las formas reales de pensar (pensar americano que es, obviamente, un pensar universal) reclama el máximo rigor en el uso del instrumental con el cual se habría de traducirlo: las palabras y sus enlaces sintácticos y lógicos. Era, en la escritura filosófica, el problema que los poetas enfrentaron en la escritura artística: se vieron forzados a reexaminar el lenguaje, a reconsiderar sus articulaciones y a alcanzar la mayor precisión lingüística del mensaje.

No es mayor sorpresa, dado el tiempo de triunfal expansión de la ciencia y la técnica que se vivía, que las metáforas con que definir la búsqueda de precisión para traducir con el mayor rigor (y el mayor realismo) el pensar o el sentir de los hombres americanos, se extrajeran de la terminología científica. Vaz Ferreira dice, con referencia al razonamiento filosófico:

Del mismo modo que los cirujanos no emprenden una operación sin desinfectar previamente todos los últiles que se proponen usar, nadie

${ }^{8}$ Op. cit., p. 7.

${ }^{9}$ Op. cit., p. 190. 
debería empezar un raciocinio sin haber dejado de antemano todas las palabras que va a emplear completamente asépticas de equívocos ${ }^{10}$.

Martí había hecho un razonamiento similar, partiendo de que "todo el arte de escribir es concretar", lo que vale por una lección de rigor y precisión, pero extrajo la metáfora definitoria de la obra literaria, de la mecánica. No de cualquiera en cualquier tiempo, sino la última, más reciente y perfeccionada, con la cual se habían construido las máquinas aparentemente perfectas que había visto a su alrededor:

Debe ser cada párrafo dispuesto como excelente máquina, y cada una de sus partes ajustar, encajar con tal perfección entre las otras, que si se saca de entre ellas, éstas quedan como pájaros sin ala, y no funcionan, o como edificio al cual se saca una pared de las paredes. Lo complicado de la máquina indica lo perfecto del trabajo. No es el dynamo de ahora la pila de Volta. Ni la máquina de Watt la marmita de Papin. Ni la locomotora de retranca de madera, la locomotora de Brooks o de Baldwin (22-156).

Es la funcionalidad de todos los componentes de la máquina, lo que aquí se alaba; su estricta adaptación a la tarea que deben realizar en conjunto para llevar a buen fin el cometido para el cual fue creada esa máquina, sin pérdida de esfuerzo ni ornamento innecesario; pero es también su complejidad lo que se celebra, equivalencia de "todo estilo bien trabado y cargado de ideas trascendentes y nuevas", como agrega, reclamando que de él se aparten los mal preparados como asimismo se apartan de las complicadas maquinarias modernas. La modernidad exige más alta preparación, más rigurosa elaboración, mayor eficiencia del producto, nítida percepción de la estructura general a la que supeditar disciplinadamente las partes.

\section{CiENCIA Y POESIA}

Coincidiendo con un pensamiento que expresó beligerantemente González Prada ("Empiece ya en nuestra literatura el reinado de la Ciencia")" también Martí propondrá "fundar la literatura en la ciencia" (22-141).

Al margen de la convergencia entre estos dos fundadores de la modernidad hispanoamericana, más aún que del restricto movimiento literario modernista, esta coincidencia reclama atención sobre una primera configuración cultural producida en el continente, la cual se extendió desde 1870 hasta mediada la siguiente década, deparándonos la poesía realista y la parnasiana (e incluso

"Op. cit., p. 32. 
esa poesía científica que tan poco ha atendido la crítica), las que encontraron en los maestros del artepurismo francés guías oportunos para una inicial tecnificación modernizadora del verso.

Martí no pretende, obviamente, "introducir el estilo y el lenguaje científicos en la literatura, que es una forma de la verdad distinta de la ciencia, sino comparar, imaginar, aludir y deducir de modo que lo que se escriba permanezca, por estar en acuerdo con los hechos constantes y reales" (22-141). Tal idea debe menos a los grandes modelos románticos (Prometheus de Shelley o Le satyre de Víctor Hugo) que a la más cercana influencia del trascendentalismo de Emerson o del panteísmo de Whitman, ejemplos de un ambicioso esfuerzo unificante de la multiplicidad aparencial.

$\mathrm{Si}$ se coordinan diversos textos martianos, puede redondearse este concepto de cientificidad, que los posteriores modernistas aceptaron sólo en lo referente a sus manifestaciones formales o técnicas, aunque no respecto al central propósito cognoscitivo que lo inspiraba al estatuir que la poesía es una forma de la verdad ${ }^{12}$. Radica básicamente en el convencimiento de que la literatura es una vía epistemológica que permite el hallazgo de la verdad, tal como paralelamente a ella lo realizaba la ciencia, aunque con la ventaja sobre ésta, de su superior capacidad abarcadora y sintetizadora de lo real, lo que le estaría rehusado a la ciencia dado que ésta operaría por múltiples vías separadas y apelando a métodos analíticos para trabajar sobre sectores siempre parciales o fragmentarios de la realidad empírica. Es bastante evidente que tal pércepción aspira a conferir a la poesía el puesto de heredera de las religiones, según había anunciado Carlyle (Heroes and hero-worship) e hicieron suyo Emerson y Whitman, antes de que se diluyera en la simbolista "religión del arte". Sin embargo, en Martí no hay sustitución: son reconocidos los campos autónomos de la ciencia y de la religión, ésta trasmutada en religión natural, y a ellos se agrega el de la poesía a la cual se le reconoce (y no así a la novela que compartiría la disgregación analítica de la ciencia, amén de servir al entretenimiento inocuo) una capacidad única para traducir el funcionamiento de lo real. Más precisamente: capacidad para descubrir las leyes que lo rigen, las que, a falta de fundamentación en la divinidad, habrían de encontrarse en el seno de la naturaleza que era también adonde iba la ciencia para descubrirlas. Que ya sobre esa Naturaleza, visualizada como término absoluto, él hubiera transpuesto subrepticiamente a la sociedad civil de su época, tal como habían hecho los trascendentalistas, invirtiendo sobre ese espejo las imágenes de la sociedad de tal modo que allí pudiera corregírsela, es otro problema que no afecta a su principal concepción del arte.

12 Es otra coincidencia con la doctrina de Manuel González Prada, quien afirmaba que "hay tres cosas que no podemos olvidar: la honradez en el escritor, la verdad en el estilo y la verdad en las ideas". Op. cit., p. 30. 
Ésta tiene que ver con el "vate", el "profeta", el "inspirado" de la época romántica aunque ya según la adaptación a que fueron sometidos tales mitos bajo el impacto deslumbrador de la ciencia mediado el XIX, abriendo campo al realismo. En el período que va de 1882 a 1890 , es decir, desde Ismaelillo hasta los Versos sencillos, Martí escudriñará con sumo interés las interpretaciones de esta nueva línea crítica, evocando las referencias de Tyndall a Emerson, como las de Moleschott a Víctor Hugo, bajo el acápite de "Ciencia y Poesía". Por dos veces registra en sus cuadernos una frase de Thomas Huxley acerca de la singularidad del espíritu científico cuando se aplica a zonas humanísticas: "En el hombre de genio, el espíritu científico toma la forma de sistemas filosófico o teológico, o poesía, que sugiere más que afirma" (21-255 y 386).

Su mención del físico inglés John Tyndall sirve de guía para situar su acuciosa meditación sobre una orientación de la lírica que pareciendo extraordinariamente moderna, acorde al cientificismo del XIX, al tiempo recuperaba una antigua tradición que venía desde los presocráticos y hacía de los poetas intérpretes cabales del mundo y trasmisores de la verdad. Las obras del discípulo y continuador de Michael Faraday, a quien sustituyó en el Royal Institute en 1867, alcanzaron en la época una gran difusión: todas sus lecciones se publicaron en Estados Unidos y sus libros se reeditaron año con año. Quien era profesor de "filosofía natural" trabajaba aún en un marco intelectual anterior a la divergencia de ciencias y humanidades que en nuestro siglo registraría Snow, de modo que sus lecciones públicas engarzaban los estudios de física, de matemáticas, de biología, con las corrientes filosóficas derivadas del idealismo alemán y, sobre todo, con las letras, representadas en sus escritos por una trilogía magna: Goethe, Carlyle, Emerson. De sus trabajos, ninguno más difundido que los Fragments of science (a series of detached essays, addresses and reviews $)^{13}$ que recogían sus lecciones magistrales en el Royal Institute, sus artículos divulgativos, sus apacibles y corteses polémicas sobre religión, evolucionismo, espiritismo, asuntos que William James tampoco dejó de examinar con atención en ese tiempo. Su discurso en la British Association de Liverpool (1870) sobre Scientific use of imagination, va precedido de dos largas citas de poemas de Emerson y de Goethe y, luego de dar ejemplos sobre cómo la imaginación enriquece la investigación científica, diseña una armonía entre las contribuciones de ésta y las concepciones espiritualistas y religiosas que en la época habían entablado ruda batalla contra la ciencia que las amenazaba. Testimonio de este equilibrio integrador que hizo suyo Martí es el siguiente extenso pasaje de su discurso:

${ }^{13}$ New York, s.f., sexta edición. 
Spirit and matter have ever been presented to us in the rudest contrast, the one as all-noble, the other as all-vile. But is this correct? Upon the answer to this question all depends. Supposing that, instead of having the foregoing antithesis of spirit and matter presented to our youthful minds, we had been taught to regard them as equally worthy, and equally wonderful; to consider them, in fact, as two opposite faces of the selfsame mystery. Supposing that in youth we had been impregnated with the notion of the poet Goethe, instead of the notion of the poet Young, and taught to look upon matter, not as "brute matter", but as the "living garment of God"; do you not think that under these altered circumstances the law of Relativity might have had an outcome different from its present one? It is not probable that our repugnance to the idea of primeval union between spirit and matter might be considerably abated? Without this total revolution of the notions now prevalent, the Evolution hypothesis must stand condemned; but in many profoundly thoughtful minds such a revolution has already taken place. They degrade neither member of the mysterious duality referred to; but they exalt one of them from its abasement, and repeal the divorce hitherto existing between them. In substance, if not in words, their position as regards the relation of spiritand matter is: "What God hath joined together, let not man put asunder"'14.

En la medida en que Martí fue un hombre para quien no sólo los países, sino todos los asuntos, debíanse ver "de raíz" en su formulación doctrinal srimera, rectora por lo tanto de las posteriores consecuencias, ideas secundarias o aplicaciones prácticas, sólo a partir de la asunción de una estética científica se diseñarán las operaciones pertinentes a la composición artística, haciendo que éstas se adecuen al propósito central, epistemológico, de la literatura. Su obra incluye numerosas referencias al arte poćtica y de ellas ninguna más reveladora que la que se encuentra en su Cuaderno de Apuntes No. 9, inmediatamente después de sus observaciones sobre "ciencia y poesía”, sugiriendo que se trata de la aplicación de sus principios normativos a la composición:

El lenguaje ha de ser matemático, geométrico, escultórico. La idea ha de encajar exactamente en la frase, tan exactamente que no pueda quitarse nada de la frase sin quitar eso mismo de la idea (21-255).

Son estas reflexiones las que podrían haber compartido los mejores modernistas, aun cuando no acompañaran su concepción raigal de la poesía; tal duplicidad de perspectivas divergentes, establece su cercanía y su alejamiento con respecto a la obra de Julián del Casal, aunque mucho menos respecto a la obra de Rubén Darío. quien también predicó el estricto encaje de idea y poesía y podría haber hecho suyo este dictamen martiano, "La poesía ha de estar en

14 Op. cit., p. 441 
el pensamiento y en la forma" (21-411), salvo que mientras Martí llegaba a él yendo por la vía del pensamiento, Darío lo hacía suyo yendo por la vía de la forma para llegar a la misma comprobación: "El clisé verbal es dañoso porque encierra en sí el clisé mental, y, juntos, perpetúan la anquilosis, la inmovilidad"15.

En la visualización martiana de la poesía, resulta robustecida su capacidad referencial: nombra lo real, descubre sus leyes, deviene un instrumento eficaz de la acción, identifica espíritu y naturaleza, conduce un mensaje de rigurosa validez como el de la ciencia. Es la suya una percepción que corresponde a la plenitud de la visión idealista-realista de mediados de siglo en la vertiente democrática que caracterizó a las letras americanas (y definió Leaves of grass en 1855) a diferencia de la vertiente artepurista de las letras francesas (Madame Bovary y Les fleurs du mal en 1857), lo que llevó a Martí a reconocer, como "cosa extraña", que "donde más idealismo hay, es en la literatura americana. A la francesa, apenas le queda" $(22-94)^{16}$. De ahí que la mayor devoción de Martí, en materia de cultura francesa, fuera la pintura de Millet o la poesía de Francois Coppée, aunque éste último le resultara un "idealista tímido" y además reconociera sus limitaciones artísticas ("Sólo en manos de Teodoro de Banville y de Catulle Mendés es el verso más flexible que en manos de Coppée" (22-290) y las limitaciones de su cosmovisión ("No alcanza la universalidad de sentimiento, grado esencial de cristalización para la viabilidad de una poesía. Lo de uno solo no interesa, sino es lo de todos" (22-298). Ambos eran "les poètes de humbles", prolongando el populismo romántico con una visión subjetiva, piadosa y conmiserativa, que no podía compararse al ímpetu jubilosamente democrático de Whitman, pero que tendría ancha descendencia en las letras hispanoamericanas entre 1855 y 1885 debido a la contextura paternalista de su tradicionalismo y a la escasa renovación democrática del período en que comenzó a emerger la modernización: buena parte de la pintura y la poesía realistas de ese período se ejercitaron en los temas piadosos, en una suerte de "arte del folletín". Su retraso, tanto respecto a las formas del satanismo y del feísmo que cultivó el arte francés hasta llegar al sensualismo mórbido de los decadentes, como respecto al ímpetu democrático y panteísta de Whitman que al tiempo era capaz de captar el entusiasmo de un Swinburne, quizás el mejor representante de ese decadentismo, definen el retraso de la sociedad hispa-

15 Prólogo a El canto errante, en Poesia, Caracas, 1977 (edición de Ernesto Mejía Sánchez), p. 302.

${ }^{16}$ La diferencia de ambas vertientes la observó nítidamente Martí. En su ensayo sobre Whitman (de 1887) anota: "Los criados a leche latina, académica o francesa, no podrían, acaso, entender aquella gracia heroica. La vida libre y decorosa del hombre en un continente nuevo ha creado una filosofía sana y robusta que está saliendo al mundo en épodos atléticos", Obra literaria, ed. cit., p. 269. 
noamericana respecto a las más dinámicas sociedades de la revolución industrial y las soluciones intermedias y graduales que iba encontrando, en letras y en artes.

Aunque Martí desarrolló, como ningún otro, una sociología de la literatura, llegado a su propia época descubría una contradicción entre su doctrina y la línea tendencial de las, para los hispanoamericanos, magistrales letras francesas. Como a muchos otros compatriotas, no sólo tradicionalistas sino también innovadores, le llevó a atribuirlo a la "decadencia europea", lugar común de la crítica en la década de los setenta acerca de la novela naturalista y la poesía parnasiana. Este lugar común ha funcionado ayer y también hoy por la dificultad para ver los diferentes procesos de los distintos focos capitalistas mundiales, sus variados tiempos de desarrollo, y para registrar, concomitantemente, el peso de las propias tradiciones culturales aun en los momentos de mayor esfuerzo modernizador ${ }^{17}$. Se daban juntas en las letras norteamericanas la modernización formal y la idealización democrática, con tal vigor que Martí se desentendió de las acusaciones morales respecto a Whitman, concediendo prioridad a su concepción de la poesía, lo que sin embargo, perspicazmente, no lo llevó a imitarlo. Veía en él una conjunción que con felicidad ha expresado el último biógrafo de Whitman:

Whitman intended Leaves of grass to be the trinitarian gospel of natural religion, democracy and science, "a modern Image-Making creation" supplying the vision which, the Scriptural Proverbialist said, "the people perish"18.

En el desembarazado manejo de la ciencia por parte de Whitman, Martí encontró su propia expectativa de un orden poético riguroso, superior aun al mismo conocimiento científico:

Ni las dudas ni la ciencia le mortifican. "Vosotros sois los primeros, dice a los científicos; pero la ciencia no es más que un departamento de

17 Estas distancias pueden medirse mejor respecto a un punto clave de la cosmovisión científica que crecía en el xix: la asunción del materialismo. Los poetas de la modernización posromántica de la segunda mitad del xixasumirán con ímpetu el materialismo, mientras que Martí seguirá procurando una vía sincrética que rescate la precisión, el rigor, el conocimiento científico y al tiempo resguarde el espiritualismo que visualiza asociado a los altos ideales redentores de la humanidad. En el Whitman de Leaves of grass, Martí podía encontrar no sólo la aceptación del universo corporal, sensual y hedónico, sino también la filosofía que lo amparaba: "I accept Reality and dare not question it / Materialism first and last, imbuing. / Hurrah for positive science! long live exact demonstration!" ("Song of myself", Leaves of grass, New York, 1891, p. 42). La misma convicción se encontrará en Rimbaud: "Cet avenir sera matérialiste, vous le voyez" (Carta a Paul Demeny, Oeuures completes, Paris, 1951, p. 256).

18 Justin Kaplan, Walt Whitman. A life, New York, 1980, p. 228. 
mi morada, no es toda mi morada; iqué pobres parecen las argucias ante un hecho heroico! A la ciencia, salve, y salve a alma, que está por sobre toda la ciencia"19.

Debido a esta concepción alta de la poesía, Martí reprobó mucha producción literaria de sus compatriotas: "poetillos jeremíacos", "literatos femeniles", "poetas de aguamiel", "figurines filosóficos o literarios", condenando no sólo la imitación torpe que le exasperaba, sino sobre todo la pequeñez, la falta de grandes ambiciones, el subjetivismo autosatisfecho, la complacencia en la pequeña historia, el convencionalismo y el atraso. Oponiéndose a esta función inferior de la poesía, llegó a establecer una clasificación de los poetas en dos grupos tajantemente separados, según quienes tenían o no tenía capacidad visionaria: entre los primeros se encontraban Emerson, Whitman, el propio Martí, pues manejaban una poesía del conocimiento global y eran capaces de percibir la macroestructura de la realidad, ahorrándose los detalles e incluso las articulaciones lógicas del discurso.

La visión global se le aparece como el imperativo de su época cultural: "No se deben citar hechos aislados - contentamiento fácil de una erudición ligera e infructífera- sino hechos seriales, de conjunto sólido, ligados y macizos" (21-168). No se trata sólo de una desmedida ambición, sino de una imposición de la historia: al extraordinario desperdigamien to de los hechos, a su incesante proliferación bajo el impulso de la nueva sociedad, era forzoso oponer una visión de la totalidad que apresara la estructura en vivo funcionamiento. En uno de sus apuntes sobre arte poética, justifica la nueva e imprescindible levedad del lenguaje artístico que alcanza en él su alquitarada forma cuando escribe los Versos sencillos, en la enormidad del conjunto del que la poesía debe dar cuenta:

Cuando se estudia con afán el mundo; - cuando se pone la mano sin miedo en sus corrientes para sentirlo palpitar; -cuando se siente interés fraternal por todo lo vivo; - cuando se vive en uno como vórtice del mundo, donde se pintan ante los ojos, en horno colosal, lo primitivo y lo heredado, lo burdo y lo culto, es fuerza que el lenguaje se resienta de sobra de peso (22-100).

\section{EL POETA VISIONARIO}

La extraordinaria rapidez de la imaginación; la emergencia tumultuosa de imágenes en la mente; la velocidad del proceso

${ }^{19}$ Obra literaria, ed. cit., p. 243. Es referencia a los versos del "Song of myself": Gentlemen, to you the first honors always! / Your facts are useful, and yet they are not my dwelling, / I but enter by them to an area of my dwelling". Sobre la 
asociativo que daba enormes saltos entre puntos dispares, cumpliendo las que serían apreciadas cualidades de la metáfora moderna, en el sentir de Réverdy y de Breton; la permanente doble lectura simbólica que asociaba estrictamente toda imagen a una significación; la casi alucinante capacidad de visualizar, literalmente, visualizar ante sus ojos las que eran invenciones de su imaginación, fueron algunas de las singulares virtudes del aparato psíquico martiano, que hasta hoy asombran. Es comprensible que le atrajeran los escritores en quienes encontraba funcionamientos similares. De Hipólito Taine, más que sus teorías, le atrae su mecánica intelectual: "agrupa lo semejante, casi sin hilación. Eso da ese aire de salto, de permanente brillantez, de novedad alta y constante a lo que escribe" (22-79).

Eso mismo vio realizado en Emerson, según dijo en el artículo que escribió a su muerte:

A veces, parece que salta de una cosa a otra, y no se halla a primera vista la relación entre dos ideas inmediatas. Y es que para él es paso natural lo que para otros es salto. Va de cumbre en cumbre, como gigante, y no por las veredas y caminillos por donde andan, cargados de alforjas, los peatones (...) Sus pensamiertos parecen aislados, y es que ve mucho de una vez y quiere de una vez decirlo todo, y lo dice como lo ve, a modo de lo que se lee a la luz de un rayo, o apareciese a una lumbre tan bella, que se sabe que ha de desaparecer ${ }^{20}$.

En los borradores de ese artículo es aún más preciso respecto al método emersoniano:

las ideas le venían en tropel y de junto, pero como secuela de una mayor, que con su altura escondía las más pequeñas, y descorrida la cual, quedaban descubiertas las que venían tras ella (19-353).

En este mismo borrador, acuña un neologismo que le sirve para definir los dos tipos de poetas y también las dos vías del conocimiento (el poético y el científico) según sus métodos: "Es hipería y no miopía" dice, oponiendo la visualización del conjunto en vivo funcionamiento desde una perspectiva (tal como Fausto al invocar el signo mágico) al registro del fragmento de realidad visto de cerca y parsimoniosamente analizado. A la obra de los poetas "hipéricos" competía el diseño de las estructuras, merced a un trazado global y sintético que las situaba en la máxima jerarquía simbólica de la cultura. De hecho, lo que tales obras representaban no eran los particulares de la realidad, sino las leyes de funcionamiento del

concepción de la ciencia por Whitman, v. JosepH BEAver, Walt Whitman poet of science, New York, 1951 .

20 Obra literaria, ed. cit., p. 243. 
conjunto. Registrando el uso de palabras extranjeras por Whitman, anota: "ensemble, sobre todo, le seduce, porque él ve el ciclo de la vida de los pueblos y de los mundos"'21. Pueblos y mundos, espíritu y materia, hombre y naturaleza: gracias al paralelismo entre la psiquis humana y el orden de la naturaleza al cual ella pertenece, esa visión global del universo era también el registro de la dinámica psíquica.

El vínculo entre ambos hemisferios, el espiritual y el material, que reclamaba John Tyndall en su discurso, sólo podía alcanzarse a través del funcionamiento en uno y otro de leyes, pues esa era la garantía del rigor de un conocimiento científico capaz de abrazar la totalidad. La frase del gran antropólogo del XIX, Tylor, que LéviStrauss gustaba repetir: Si hay leyes en algún lado, hay leyes en todas partes. La ciencia las había establecido en el mundo natural; a la poesía competía encontrarlas en el espiritual y era lo que reclamaba Martí en su "Pollice verso" de Versos libres: "Hay leyes en la mente, leyes / cual las del río, el mar, la piedra, el astro, / ásperas y fatales" (16-136). Capturar esas leyes, no en su formulación estática sino en su peculiar funcionamiento, se constituyó en codiciada meta de Martí, aun a sabiendas de la extremada dificultad que se oponía al registro de algo tanto más veloz que todo lo que se conocía en el mundo natural: "QQuién pudiera fotografiar al pensamiento, como se fotografía al caballo en la carrera y al ave en su vuelo!" (21-385).

No puede sorprender que Martí haya utilizado como precisa simbolización del poeta, la metáfora del águila. Es índice de la empinada sacralización del poeta y de la poesía que llevó a cabo (tan reclamada por la desam parada comunidad latinoamericana, entonces y aun hoy mismo, por el peso que la aristocracia letrada alcanzó en comunidades mayoritariamente analfabetas) y también un índice del hervor animalista de las imágenes que puso en circulación quien fue, paradójicamente, uno de los tesoneros exponentes del espiritualismo y que en uno de sus apuntes recogió esta definición de Kingsley: "Man is a poetry writing animal" (21-418).

La muy elevada idealización, el alto sitial concedido al espíritu, la energía de una religión natural, van acompañados de un cortejo de animales, seleccionados mediante un régimen simbólico simple, a veces meramente tradicional, que prácticamente los convierte en signos con los cuales visualizar al universo y, sobre todo, significarlo: "La vida tiene sus bestias y sus fieras, sus pavos reales y sus águilas". A veces funcionan como transposiciones de las pugnas de la sociedad civil: "Es lucha de perros y de osos". Otras traducen las jerarquías morales, oponiendo "esos gusanos de pesado vientre / y ojos viscosos, que en hedionda cuba de pardo lodo lentos se revuelcan" a "una paloma blanca" (16-135). En ocasiones, el propio yo es

${ }^{21}$ Obra literaria, ed. cit., p. 276. 
transformado, por la sociedad, en "caballo" o en "jamelgo". Y otras, el rostro se animaliza en una imagen disonante: "Sueñoleporino del que duerme con los ojos abiertos, como la liebre" (21-258).

Esta animalización será perceptible en otros modernistas, particularmente en Darío, quien también les confiere calidad sígnica utilizando la lección dada por Leconte de Lisie, aunque ya permitiéndose el regusto perverso del decadentismo ("y cuando tiende al hombre la gran Naturaleza / el monstruo, siendo el símbolo, se viste de belleza"). En ninguno, no obstante, tiene la frecuencia y la intensidad que encuentra en Martí, situado dentro del sistema analógico hombre-animal que desde el materialismo del XVIII se posesionó de la cultura europea, tuvo expresión en el fisiognomismo de Lavater, fue gráficamente explotado por los dibujantes, incluyendo al Gavarni que Martí admiraba (posiblemente no sólo por su arte sino también por sus posiciones sociales) y obtendría fundamentación desde el Origen de las especies. El animalismo culmina, en las literaturas europeas, en 1869, cuando la publicación del libro del uruguayo-francés Isidore Lucien Ducasse Les chants de Maldoror, que si pasó desapercibido en Francia con más razón fue desconocido por los hispanoamericanos hasta que Darío le concedió uno de los ensayos de Los raros (1896), a partir de una información de segunda mano. Es esa obra el exponente máximo de una tendencia generalizada que pone su sello sobre las diversas poéticas que en el período 1855-1885 registran la irrupción violenta de la modernidad. Las diferencias con que ella se formula en los diversos autores, no disminuye la comprobación de que en el imaginario de todos sus autores la modernidad viene acompañada de un cortejo animal y, sobre todo, de una energía desbridada que no puede compararse a otra cosa que a la ferocidad bestial. Para todos sirve de consigna una frase de Rimbaud en Une saison en enfer: " $j$ 'ai fait le bond sourd de la bête féroce".

La relación del animalismo de las imágenes y la potencia del voluntarismo humano arrojado a una actividad incesante, sin tregua, ofensiva-defensiva, quedó nítidamente establecida por Lautréamont:

Chaque animal impur qui dresse sa griffe sanglante, eh bien, c'est ma volonté qui, pour donner un aliment stable à son activité perpétuelle, les fait tourner en rond ${ }^{22}$.

Es una energía feroz que Gaston Bachelard razonó como el centro del complejo animador de la obra ducassiana: "C'est le complexe de la vie animale; c'est l'énergie d'agression. De sorte que

${ }^{22}$ Les chants de Maldoror, en Lautréamont / Germain Nouveau, Oeuvres completes, Paris, 1970 (ed. Pierre-Olivier Walzer), p. 196. 
l'oeuvre de Lautréamont nous apparaît comme une véritable phénoménologie de l'agression"23. Tal agresión genera cruel y profunda tortura hasta alcanzar la muerie del otro y es, para Alain Paris, "l'expression directe, instantanée, naturelle, de l'élan vital de l'animal" 24 , atribuyendo su origen a un concepto darwiniano que alcanzó una enorme boga en el mundo desde su aparición ein 1859: "the struggle for life". Si así fuera ${ }_{s}$ habría revertido a su origen; más de una vez se ha señalado que los principios económicos (Malthus) y los sociales de la era victoriana habrían servido para instrumentar la teoría darwiniana ${ }^{25}$, que diseñaría en el reino natural un homólogo del capitalismo salvaje que había alcanzado su máxima violencia y competitividad. La aparición entre los modernizadores poéticos de una constelación de imágenes que traducen esa energía animál, instintiva, sin freno, que tortura y mata, corresponde al período de ácida expansión del capitalismo en las sociedades occidentales, llevando a su ápice la ruptura entre individuo y mundo que había caracterizado al romanticismo de comienzos del XIX.

Dota al contorno social de una hostilidad máxima y, paralelamente, al individuo de una extremada tensión en que puede acentuarse, alternativamente, la nota defensiva o la agresiva. Es ésta la que prima en la vertiente europea de la modernización, ya en la ferocidad destructora de Lautréamont, ya en la asunción del mal, de Baudelaire a Rimbaud, y, contemporáneamente, en Swinburne, extendiéndose por un período que estuvo caracterizado por una violenta compresión social, movida por factores económicos, de la cual nace la emigración de millones de seręs humanos que se trasladan a diversos puntos del planeta buscando modos de sobrevivencia, en especial a América, desde los Estados Unidos hasta la cuenca del Río de la Plata.

La vertiente americana no deja de registrar la misma energía animal según es visible en el eje interno cuyos polos ocupan Whitman y Martí respectivamente, pero la traduce a una fruitiva materialidad, a un goce de los sentidos, a una vulgaridad y concupiscencia francamente reconocidas, en el primero, o la regimenta dentro de un orden ético rradicional y, desde luego más convencional, en el segundo. Martí percibe con inquieta admiración "ese lenguaje henchido de animalidad soberbia" que singulariza a Whit" man, y agrega: "en ocasiones parece el lenguaje de Whitman el frente colgado de reses de una carnicería" ${ }^{26}$. Esta carnalidad brutal

23 Gaston B achelard. Lautréamont, Paris, 1974 (3a. ed, aum.) p. 9.

24 Alain Paris, "Le bestiaire de chants de Maldoror", en Quatre lectures de Lautréamont, Paris, 1972, pp. 138-139.

${ }^{25}$ John D. Bernal, Historia social de la ciencia, Barcelona, 1979, t. 1, p. 497. El análisis de los marcos ideológicos de la ciencia del xix, con particulaı atención a la teoría evolucionista, en Pierre Thulllier, Darwin \& Co., Paris, 1981.

${ }^{26}$ Obra literaria, ed. cit., pp. 273 y 275. 
está, sin embargo, puesta al servicio del goce y es sólo su exceso, su impudor, lo que Martí puede catalogar bajo el rubro demoníaco: "la enumeración de satánica fuerza en que describe, como un héroe hambriento que se relame los labios sanguinosos, las pertenencias del cuerpo femenino"'. Pero no se equivoca al encontrar allí una de las dos fuentes de la originalidad whitmaniana: "es la forma material, brutal, corpórea, con que expresa sus más delicadas idealidades"27. De otro modo, esa energía animal no sólo traduce el capitalismo salvaje, sino también la democratización que dentro de él se formula. Un pueblo, puesto dentro de sus implacables leyes agresivas, las hace suyas al servicio de los campos en que puede realizarlas sin perder los ideales originarios en que se ha formado. Imita, pues, los principios materiales que desde la cúpula ordenan a la sociedad, hace suyos los métodos brutales de apropiación, trasladándolos preferentemente al campo sexual en donde tiene posibilidades de acción libre, pero procura conservar los principios solidarios, de grupo, de clase, en los cuales se prolongan los ideales que sus orígenes y su educación les han proporcionado.

La energía animal puebla asimismo el universo poético martiano, aunque delimitada y distribuida dentro de un orden intelectual explicativo que todavía debe mucho a los esquemas tradicionales con que la religión impregnó la cultura hispanoamericana: lo alto y lo bajo, lo celestial y lo terrenal, lo legítimo y lo ilegítimo. La mayoría de sus imágenes o comparaciones animalizadas se refieren a la sociedad, para cuya hostilidad y salvajismo ${ }^{28}$ tiene un repertorio casi ducassiano: es el "tropel famélico de hirsutas fieras" (16-143), es "una jauría" que se abalanza sobre el joven "cual comido de fieras" (17-289), es el caballo que ve "garras y dientes de tremendo lobo" (16-183), el amor "comido de hienas" (16-179), el alma que se nutre "de dientes de fiera" (17-304), son en definitiva los "voraces hombres" (16-173), pues "jaulas de carne / son hoy los hombres" (16-207). Está ausente el fantástico despliegue de la imaginación ducassiana, pero está presente su "griffe", que en Martí se pone al servicio de una acción privilegiada: comer, devorar, alimentarse del otro, apropiárselo en su propio beneficio. Para la esfera superior y demoníaca, que corresponde al ejercicio pleno del mal, quedan reservados los insectos: "el mal, como un insecto, sus oscuros / anillos mueve ý sus antenas clava" (16-205) y es comprensible

27 Op. cit., p. 272.

${ }^{28}$ Martí está bien lejos del populismo beato del xx ("El hombre es bueno") y en uno de los poemas de desahogo de Versos libres, "Yo sacaré lo que en el pecho tengo", consignó su estado "de cólera y de horror" ante la experiencia del mal por parte de los hombres ("es que a los hombres / palpo, y conozco, y los encuentro malos" o "conozco al hombre y lo he encontrado malo") restableciendo la relación victimario/víctima: "fea! clave / el tigre bien sus garras en mis hombros: / los viles a nutrirse: los honrados / a que se nutran los demás en ellos" (16-222-5). 
que a ellos corresponda el deicidio: "un Dios que muere / remordido de hormigas" (17-317).

Las imágenes son frecuentemente convencionales, y su selección responde a una estructura de significaciones simple. Del mismo modo que los asuntos amorosos trasponen las comparaciones al universo vegetal, o, dentro del animal, a las aves, del mismo modo, los animales se distribuyen a lo largo de un eje vertical, cuyo polo inferior ocupa la materia (los gusanos, las sierpes) y el superior el espíritu libre (las aves, las mariposas, las águilas) hasta culminar, más allá de los espacios, en la estrella. Esta "águila blanca" a que incesantemente apela Martí, pertenece a una cadena de símbolos que se extiende desde el "albatros" baudelairiano hasta el "cisne" mallarmeano-dariano en esos cincuenta años del capitalismo salvaje expandiéndose por el mundo: es el poeta, pero es, sustancialmente, la libertad humana en oposición a la constricción social. Las “águilas alegres" (16-184), las “magníficas águilas" (17-297), sólo aparecen como deseo para contrastarse con "el águila (que) se arrastra" (17-287), con "el águila rastrera" (16-168), que ofrecen la versión realista, lo que desde su prólogo al Poema del Niágara de Pérez Bornalde, en 1882, explicó claramente, refiriéndose a los artistas:

Es su natural oficio sacarse del pecho las águilas que en él les nacen sin cesar - como brota perfumes una rosa, y da conchas de mar y luz el sol- y sentarse, a par que con sonidos misteriosos acompañan en su lira a las viajeras, a ver volar las águilas: pero ahora el poeta ha mudado de labor, y anda ahogando águilas ${ }^{29}$.

Los tres rasgos anotados de la estética martiana: el rigor cognoscitivo atribuido a la poesía, el nivel superior en que puede dar cuenta de la macroestructura del universo diseñando sus leyes, y la utilización de repertorios de imágenes cargados de significación precisa que los reconvierten en signos, pueden explicarse - y efectivamente algunos de esos rasgos lo han sido- por una impostación realista de su arte.

No es así. El realismo aparecerá, al nivel del arte poética, como mero resultado de una fuerza mucho más amplia, mucho más intrépida y original, que es la potencia visionaria.

Martí es el mayor, más exactamente, el único gran poeta visionario de América Latina y en ningún otro poeta de su tiempo, ni siquiera en aquellos que clausuran el romanticismo, como Joaquim de Sousa Andrade, se podrá encontrar un abanico de visiones tan espléndidas y terribles, ni una operación visionaria tan minuciosamente registrada y elevada a la categoría fundacional de la poesía.

29 Obra literaria, ed. cit., p. 206. 
También aquí, para encontrar un adecuado término comparativo sobre el cual medir semejanzas y diferencias, hay que recurrir al eje internacional de la modernidad. El punto de referencia está fuera del marco latinoamericano y lo define la lección de Rimbaud. La comparación resulta fructífera, siempre y cuando se reconozca a ambos poetas colocados sobre ese mismo eje de transformación revolucionaria de la poesía en un momento de crucial palingenesia, aunque ocupando polos opuestos. A la drástica negatividad rimbaudiana (como a la ducassiana) responde una positividad martiana, de tal modo que si ambos coinciden en igual problemática y, lo que es más importante, en la misma experiencia abisal, resuelven el desafío dentro de los parámetros culturales propios, que son, obligadamente, los de sus sociedades específicas en diferentes posiciones ante una metamorfosis arrolladora. Tanto vale reconocer que el fenómeno transformador fue, con una fuerza nunca antes vista, universal, no dejando zona cultural del planeta sin tocar y alterar, pero las soluciones dadas por ios escritores mostraron sensibles diferencias según las circunstancias de cada región, sus herencias culturales oropias, el grado de intensidad que mostraba el nuevo orden económico-social, la profundidad generadora que tenía en unas respecto a la dependiente y operativa aplicación que tuvo en otras, etc. El eje que vincula las invenciones estéticas europeas (del artepurismo al decadentismo) con las aportaciones americanas (de Poe y Whitman a Martí y a Darío), no impide reconocer la existencia de ese otro eje estrictamente americano definido por los nombres de los poetas de Estados Unidos y los de América Latina, desfasados en el tiempo aunque igualmente apegados al gradual desarrollo del nuevo modelo social que iba contaminando al planeta. Este eje americano tuvo un punto de contacto privilegiado gracias al traslado de Martí a los Estados Unidos en 1880 que le permitió llevar a cabo una conjugación máxima de experiencias sociales, culturales y artísticas, tal como tempranamente vio Federico de Onís ("La concepción de América de Martí, como la ruta de su vida, se mueve en el triángulo: Hispanoamérica-España-Estados Unidos, la misma ruta y concepción que seguiría Rubén Darío poco después y más o menos fielmente la mayor parte de los modernistas" 30 aunque con más precisión debería leerse, en vez de España, Europa, dado el flagrante peso que cabe a las estéticas franco-inglesas, por encima de las españolas) y le permitió una experiencia cultural única por su casi década y media de convivencia con la modernización norteamericana, cuya importancia en la formación artística de Martí ya fue realzada por Enrique Espinoza, para oponerse explícitamente a la interpretación hispanizante en boga ("Apenas se ha estudiado hasta hoy la influencia que tuvo en Martí el conocimiento directo de la

${ }^{30}$ España en América, San Juan, 1968, p. 626. 
gran literatura norteamericana del siglo XIX y su adhesión a la filosofía de Emerson. En cambio se viene hablando cada vez más copiosamente de la españolidad de Martí, de lo teresiano y lo quevedesco en Martí, aparte de otras vejeces venerables"'31). La mutación que a partir de esta incorporación a uno de los centros de modernización se produjo en la literatura martiana, fue reconocida por el autor, sin mengua de su de sobra conocida oposición al imperialismo y al orden económico-social norteamericano, cuando en su carta-testamento a Gonzalo de Quesada (Montecristi, $I^{0}$ de abril de 1895), le pide: 'Versos míos no publique ninguno antes de Ismaelillo: ninguno vale un ápice. Los de después, al fin, ya son unos y sinceros" (20-447).

El tema del poeta visionario reclama, aun más que el eje interno americano (Whitman-Poe), el europeo-americano, porque la plena afirmación de esta perspectiva pertenece a Rimbaud y a Martí. La famosa carta que Arthur Rimbaud escribe a Paul Demeny desde Charleville el 15 de mayo de 1871, conocida en la historia literaria como la "Lettre du Voyant", puede leerse, alterando su signo, sobre el propósito artístico de Martí. Tal paralelismo revierte en una mejor comprensión de los propósitos artísticos de ambos y de la relación estrecha que esos propósitos guardan con las circunstancias profundas de la modernidad cultural. El texto de Rimbaud proclama flamígeramente la condición de "visionario" a la cual se llega mediante un sistemático trastorno del psiquismo al asumir igualitariamente el bien y el mal:

Je dis qu'il faut être voyant, se faire voyant.

Le Poëte se fait voyant par un long, immense, et raisonné dérèglement de tous les sens. Toutes les forces d'amour, de souffrance, de folie; il cherche lui-même, il épuise en lui tous les poisons, pour n'en garder que les quintessences. Ineffable torture où il a besoin de toute la foi, de toute la force surhumaine, où il devient entre tous le grand malade, le grand criminel, le grand maudit, et le suprême Savant. Car il arrive à l'inconnu's?.

A quienes cultivan la imagen estereotipada y sacralizada de Martí podrá repugnar la aproximación con un "poeta maldito", así se trate del fundador del arte moderno, de quien Martí tuvo escasísimo conocimien to y a quien cita de segunda mano en sus cuadernos hacia 1890 cuando descubre la existencia de Paul Verlaine, cuya poesía sí creo que contribuyó a la contemporánea redacción de los Versos sencillos. El cotejo no pretende restar nada a la innegable "eticidad" de Martí, quien nunca hubiera podido asumir en sí al

31 "Marti ahora" en Archivo Martí, La Habana, 1945, núm. 10, 323-327. p. 254.

${ }^{32}$ Oeuvres completes, Paris, 1951 (ed. Rolland de Renéville y Jules Mouquet), 
"grand criminel", pero que en cambio se percibió a sí mismo siempre como el "grand malade" y el "grand maudit" y que, como los visionarios, los héroes individuales solitarios y como incluso los santos, pudo percibir de modo repentino y fulgurante que la aberración de la sociedad colocaba al iluminado en la categoría de monstruo y de criminal: "cual un monstruo de crímenes cargado/todo el que lleva luz se queda solo" (16-161).

Aun los críticos reverenciales de la cualidad apostólica martiana, no han dejado de reconocer la abismal y persistente experiencia del dolor que llevó a cabo Martí a lo largo de casi toda su vida y la voluntaria inmersión en una experiencia casi alucinatoria del sufrimiento. Si para alcanzar el "déreglement de tous les sens"' Rimbaud prescinde de la ética aceptada, vigente en la sociedad, y hace suyos tanto el bien como el mal sobre un bajo continuo de sufrimiento, Martí no es menos sistemático, ni menos "raisonné", ya que siendo inocente asume (diríamos que dostoievskianamente) todo el mal que se produce en la sociedad. Igual que Rimbaud, Martí reconoce una imposición distorsionadora y constante de la sociedad, de la que reniega doctrinalmente, pero la que acepta, hace suya, vive íntegramente. Ese "gozarse en la pena, en regodearse en la tortura interna que llega a la bendición del dolor" como ha dicho Juan Marinello, no es tarea inútil para Martí, quien ve en ella una obligada condición para alcanzar la plenitud expresiva, tal como lo entendió Rimbaud. Cuando dice "el dolor alimenta, el dolor purifica, el dolor nutre" 33 podría creerse que estamos en un resabio de su educación católica, pero cuando establece que "así de mi dolor se escapa el verso" (16-247), nos engañaríamos si lo leyéramos como un viejo esquema romántico, pues es el reconocimiento de una relación de producción, un canje en un mercado de oferta y demanda, un análisis de la singularidad de la máquina productiva que es el hombre-poeta de acuerdo con las pautas de una determinada sociedad y época. Así lo examinó con precisión en los años de Versos sencillos:

Para pensar altamente me hace falta sufrir. Primero, caigo, tambaleando y muriendo. Y me levanto, con el cerebro en hervor, y el alma ágil. Brotan mis pensamientos como chispas. Parece como que el puñal que me entra en el cerebro, echa hacia adelante las ideas. Suben en alto, como espumas rotas, al chocar de la ola con la roca, como mina volada de diamantes, llameando al Sol (21-234).

O en forma aforística: "El dolor de ideas poéticas" (22-323).

Rimbaud pone el trastorno psíquico al servicio exclusivo de una especialización: la formación del Poeta. Para Martí es mucho más: se trata del prerrequisito obligado para construir al Héroe y, aún más, al Mártir, por lo cual el dolor tiene que alcanzar la máxima

ss "El presidente Garfield", La Opinión Nacional, Caracas, 19/oct/1881. 
intensidad para que repercuta armónicamente en una máxima elevación espiritual, que alimenta esa trilogía que él buscó unificar dentro de sí: Poeta-Héroe-Mártir. La tremenda frase, "Tengo miedo de morir antes de haber sufrido bastante!" (21-191) se complementa con otra opción, mucho más difícil. Martí parte de la misma comprobación que había hecho Baudelaire al reflexionar sobre el desequilibrado funcionamiento emocional de la sociedad, pues también él reconoce que los sistemas jerárquicos y opresivos de una sociedad, impregnan los comportamientos subjetivos, las relaciones espirituales, las formas de la afectividad, aseverando entonces que "La cuestión en la vida está reducida a una simple frase: o hacer víctimas o serlo" (21-241). A partir de esa comprobación decide asumir, voluntariamente, el papel de víctima: "me place el sacrificio / más que el gozo común" (21-385), dice en uno de sus apuntes para un borrador poético; y en sus Cuadernos, repentinamente, registra sin un solo comentario la conocida fórmula baudelaireana: "Heautontimoroumenos (el verdugo de sí mismo)" (21-401).

Este "verdugo de sí mismo" que fue conscientemente José Martí, no puede explicarse por su heroico sacrificio a una causa patriótica, como hace la acuñada visión apostólica. De Bolívar en adelante, América dispone de una poblada galería de altos héroes que se sacrificaron por sus patrias sin que en ellos resonara este acento autotorturante. Puede buscarse su sentido refiriéndose a una peculiaridad de su naturaleza, según varias anotaciones de sus apuntes:

Hay naturalezas ferozmente dotadas. Los efectos tranquilos no les bastan. La guerra es su elemento. Son mares hirvientes. Parecen hechos de lava y de aire de tormenta. Enamorados de la calma, no pueden vivir en ella. Inmensamente activos, necesitan una pasión que los devore. Buenos - yerran; puros - pecan; nobles - cometen villanias; es exceso de ardor: es accidente. La forma de pasión y su objeto importan poco: la pasión les es precisa.

Tal visión puede vincularse a las diversas anotaciones sobre el "yo" de sus cuadernos iniciales $(21-68,69)$ donde también se registra esa mínima distancia entre el bien y el mal en la conciencia humana y ese repentino e involuntario desplazamiento de quien, al procurar el bien, encuentra el mal, asunto que resurge diez años después cuando recensa las conferencias del Congreso Antropológico en los Estados Unidos, interesado en el análisis que los científicos sociales hacen de estos comportamientos:

Todos los crímenes, todas las brutalidades, todas las vilezas, están en germen en el hombre más honrado. Lo más vil o bestial ha aparecido en algún instante posible o deseable al alma más limpia ${ }^{34}$.

34 "Un Congreso Antropológico en los Estados Unidos", La Nación, Buenos Aires, 2/agosto/1898. 
También puede buscarse el sentido de estas vivencias en un plan razonado de "hacerse a sí mismo" de conformidad con un altísimo ideal, una suerte de super ego que se sabe inalcanzable, hacia el cual se tiende con anhelo a pesar de que eso no hace sino patentizar las imperfecciones propias y las propias insuficientes fuerzas, las que adquieren entonces una cualidad vengativa. No dice otra cosa el poema "Pollice verso" de Versos libres que estatuye que "circo la tierra es, como el romano" donde los hombres luchan bajo miradas que los evalúan y pueden condenarlos:

Mas el pueblo y el rey, callados miran

de grada excelsa, en la desierta sombra.

¡Pero miran! Y a aquel que en la contienda

bajó el escudo, o lo dejó de lado,

o suplicó cobarde, o abrió el pecho

laxo y servil a la enconosa daga

del enemigo, las vestales rudas,

desde el sitial de la implacable piedra,

condenan a morir, pollice verso (16-137).

La ambición de altísima autorrealización, según modelos sociales que han sido internalizados, resulta bivalente: eleva y condena, justifica la existencia y prueba su imperfección, tal como la bien conocida experiencia de la hagiografía mostró durante siglos. La bivalencia de esa aventura espiritual también ha sido señalada para Rimbaud, tironeado entre el demonismo y la redención angélica. En el caso de Martí hay abundantísimos datos personales que muestran las fuentes biográficas de un complejo doctrinal que él definió con la relación heroica padre-hijo. Pero a ellas se suman otras fuentes sociales, que tanto proceden del sistema de imperativas exigencias, casi confiscatorias de la vida y la subjetividad humanas, que encontró en el régimen de trabajo de los Estados Unidos, como en un rasgo que él allí descubrió propio de los latinoamericanos, a quienes, dijo, "la nostalgia de un mundo espiritual superior los invade y aflige" 35 . En el cruce de estas plurales tendencias, personales y sociales, se sitúa la experiencia del "Heautontimoroumenos".

Como en Rimbaud, esta experiencia psíquica sostiene la cualidad visionaria. La palabra "ver" quedará íntimamente ligada, para él, a la elaboración poética. En el citado ensayo sobre Emerson, la exalta: "Dijo lo que vio; y donde no pudo ver, no dijo"; "Da cuenta de sí y de lo que ha visto"; "Donde ya no ven sus ojos, anuncia que no ve". Son las mismas palabras de la carta a su hijo con la cual prologa el Ismaelillo: "Tal como aquí te pinto, tal te han visto mis ojos. Con esos arreos de gala te me has aparecido. Cuando he cesado de verte en una forma, he cesado de pintarte" (16-17). Es la nota

35 “Coney Island", La Pluma, Bogotá, 3/dic/1881. 
visionaria que registra en las cartas íntimas a los amigos a quienes remite un ejemplar del libro: "No sé si he acertado a dar forma artística al tropel de visiones aladas que cuando pienso en él me danzan en torno de la frente" (20-298) le dice a Gabriel de Zéndegui, y a Enrique José Varona: "fue como una visita de rayos de sol" (20-299). En su privado Cuaderno de Apuntes, consigna:

Ni una sola de las imágenes de este pequeño libro ha dejado de ser vista por mis ojos, con sus formas, proporciones, y esto antes de venir en forma de versos a los labios. Y cuando la imagen se ha desvanecido, allí he escrito el último verso donde se desvanecía, extinguido el fuego, la impresión (21-221).

Obsesivamente, como luchando contra la eventual incredulidad de sus lectores, dice lo mismo en el prólogo a Versos libres:

Lo que aquí doy a ver lo he visto antes (yo lo he visto, yo), y he visto mucho más, que huyó sin darme tiempo a que copiara sus rasgos. De la extrañeza, singularidad, prisa, amontonamiento, arrebato de mis visiones, yo mismo tuve la culpa, que las he hecho surgir ante mí como las copio. De la copia yo soy el responsable (16-131, 2).

Y en la citada carta-testamento, cuando ya está "con las ansias de la muerte”, le repite a su fiel Quesada: “QQué habré visto sin sangrar, ni pintado sin haberlo visto antes con mis ojos?" $(20-477)^{36}$. Se trataba de una norma de la creación: "Necesito ver antes lo que he de escribir" (21-186) anota en sus Cuadernos, reiterando esas dos palabras de quien busca persuadir de una experiencia verdadera poco creíble: ver y antes del verso, ver con los ojos, ver en la realidad, no soñar, sino ver, concretamente, lo que pasa a ser, literalmente, una visión. Que en ello había un proclividad casi sobrehumana de su naturaleza, los textos parecen probarlo, pero que en ello también puso una voluntariedad para, rimbaudianamente, "se faire voyant", se lee en la citada anotación de sus Cuadernos, que continúa en estos términos: "Me creo, estudio, reconstruyo en mí los colores y el aspecto de lo que tengo que pintar" (21-186). Este comportamiento se cristaliza en 1881-2 (años de extraordinarios padecimientos) cuando escribe Ísmaelillo. Es comprensible que en su carta a Vidal Morales, le haya dicho que "fue como la visita de una musa nueva" (20-297). Ciertamente la de la musa visionaria, la misma que hizo decir a Whitman: "speech is the twin of my vision".

36 Los ejemplos pueden acumularse. En uno de sus fragmentos, que quizás haya sido un borrador del prólogo a Flores del destierro, luego desechado, dice: "Perdón por esta culpa mía de ofrecer, en vez de un ramo de flores, un haz de relámpagos (...) Y si nacen a mis ojos, por voluntad extraña a la mía, ¿cómo evitar que los ojos caigan sobre ellas; y si mandan que las pinten como si fuesen espadas de fuego movidas por capitán invisible, cómo me libraré de su mandato?" (22-317). 
JE EST UN AUTRE

La nota visionaria irá acompañada de otra, mucho más inquietante, que sólo pudo interpretarse como pervivencia del concepto romántico de inspiración debido a que el mismo Martí aún le aplicó la terminología del romanticismo, hablando frecuentemente de musa. Se trata de la producción automática de la poesía, sin aparente participación de la conciencia del escritor, en una singular operación que no puede confundirse con la escritura automática de los surrealistas del Xx porque tal como se da en el grupo de los poetas de la modernización de mediados del XIX tiene curiosas notas que la diferencian. Estos distingos, respecto a los anteriores románticos como a los posteriores surrealistas, no dejan de reconocer que lo que tratamos de caracterizar es un momento particular de un proceso muy amplio que abarca sucesivos estadios desde la revolución burguesa triunfante que puede abrirse con el Fausto goetheano que testimonia la existencia en su pecho de dos almas. En el momento correspondiente a los modernizadores, se percibe la génesis espontánea de la poesía en el psiquismo bajo la mirada atenta de un yo; éste, merced a un subrepticio desdoblamiento, deviene un testigo, en el mejor de los casos un colaborador experto, de una operación creadora que realiza dentro del psiquismo un extraño, "un autre" cuya denominación es difícil y escurridiza, porque ya puede ser un paralelo del "yo" consciente y entonces es posible de ser encajado en una dicotomía tradicional, mediante reacomodación de sus términos, designándolo con el nombre de "alma", ya puede percibirse que es el "yo" terrenal, no metafísico, que se ha enajenado en un otro. Esta es la comprobación de Rimbaud, en tanto la primera es la de Whitman, aunque en ambos la diferencia entre esas dos miradas cognoscitivas radica en que a la pequeñez, subjetividad, escaso conocimiento y poder de una, se opone la fuerza, omniciencia, originalidad y penetración lúcida de la otra, que además es religadora, ya con el vasto mundo real, ya con la sociedad íntegra. En todos los casos, el fenómeno es autocontemplado por el escritor, con inquietud y perplejidad, sin lograr despejar su significación pero comprobando su existencia. Así en el Whitman de Leaves of grass:

I cannot understand the mistery, but I am always conscious of myself as two - as My Soul and I; and I reckon it is the same with all men and women ${ }^{37}$.

${ }^{37}$ The uncollected poetry and prose of Walt Whitman (ed. Emory Holloway), New York, 1921, t. 2, p. 66. El fragmento corresponde a una fecha de fines de los años cincuenta (1848 ó 1849), lo que lo vincula a la "revelación" de la cual arranca Leaves of grass y que tantas especulaciones motivara en la crítica. V. R ICHARDMAU. RICE Bucke, Cosmic consciousness, New York, 1923 y G Ay W ILson $A_{\text {Llen, The new }}$ Walt Whitman handbook, New York, 1975. Este observa, sobre la primera biogra- 
Posiblemente es esta singularidad la que le autoriza a decir que "I dream in my dream all the dreams of the other dreamers / and I become the other dreamers", lo que Martí comprueba al hacer su lectura: "Padece, sí, padece; pero mira como un ser menor y acabadizo al que en él sufre, y siente por sobre las fatigas y miserias a otro ser que no puede sufrir, porque conoce la universal grandeza" 38 .

A lo largo de su poesías, Martí insiste en esta involuntariedad del fenómeno: la poesía se produce dentro de él, no es que él la produzca, o la busque, y, todavía más, estatuye que no es correcto buscarla porque entonces se rehusaría, lo que vale por reconocimiento de su autonomía. El automatismo psíquico poético se traduce con formas de la cortesía que evocan las explicaciones románticas ("Jamás en sus vagares la interrumpo / ni de su ausencia larga me impaciento") y reitera la humilde aceptación de sus imposiciones, así sean las más duras: "¡Viene a veces terrible! ¡Ase mi mano, / encendido carbón me pone en ella / y cual por sobre montes me la empuja!"'(16-227).

Tal entendimiento de la operación poética, varias veces reiterado por Martí, no debe sin embargo ser reducido a este único campo, sino que hay que reconocerlo como una parte, importante sin duda, de un descubrimiento mayor: los múltiples automatismos que funcionan en el ser humano sin cruzar por su conciencia ni ser movidos por su voluntad. Así, por ejemplo, habló de "la inteligencia del cuerpo", al reconocer que éste era capaz de actuar, maquinalmente, por sí mismo: "Los movimientos inteligentes de los músculos. Otra especie de inteligencia, que dirige los actos que se llaman "maquinales" (21-404). Más sutil aún es su descubrimiento de lo que llamó "la inteligencia de la mano", por cuanto se refiere a un automatismo vinculado con la escritura. Lo registró, observando que era capaz de actuar dentro de un sistema estructurado, al percibir un primer error ortográfico de la mano, que luego habría de ser enmendado compensatoriamente:

se equivoca, al escribir pan, y escribe han. En vez de una letra labial, pone otra labial. Aun en su abandono, la inteligencia obra Composición, por partes y elementos, de la inteligencia. Y en dos palabras seguidas, al equivocar una letra ( $b$ an bueno), dirá luego la letra que cambió: ban (pan), pueno (bueno) (21-398).

En el citado artículo sobre el Congreso de Antropología, su estima por el reverendo Turlug, responde a que éste reconoce la

fía de Bucke, "The double nature of poet, a profound spirituality mingled with an exuberant animality, remains a paradox in the biography - though it is not treated as such" (p. 9).

${ }^{38}$ Obra literaria, ed. cit., p. 274. 
"mente automática" y llega a decir de él que ha entonado un cántico al alma: "Él cree en la obra involuntaria de la mente, en la atracción, unidad y fuerza de los espíritus".

Pero la manifestación más amplia de este automatismo, capaz de abarcar la existencia personal entera, es también la percepción más extraña que Martí hizo de sí mismo en una fórmula muchas veces repetida: "Yo que vivo aunque me he muerto" (Versos sencillos, 16-101); "He vivido; me he muerto: y en mi andante fosa sigo viviendo "(Versos libres, 16-173); "Que yo voy muerto, es claro" (16-192); o en una cuarteta de sus apuntes: "La ciudad es grande, cierto, / y rica, y brillante, y bella, / y yo soy un hombre muerto, / y mi sarcófago es ella" (21-181). Un verso de Flores del destierro restablece la ecuación productiva sufrimiento / poesía ("Muerto como hombre y como sol sereno" 16-240) guiado hacia el oxímoron con que conjugará ambos términos en una cuarteta de sus borradores:

Solo, como la llama desprendida de un cadáver que, en el desierto, como un sol funeral cruza la vida, como un rey, como un mármol, como un muerto (21-401).

Este "sol funeral", que responde armónicamente al "soleil noir" nervaliano y que es "sereno" y grave como es el ritmo pausado de la cuarteta (a poner entre sus más pulcras y misteriosas poesías), traduce íntegro este clima onírico que curiosamente no es producto de una despersonalización, pues el "yo" está presente, en una sobrecogedora transparencia, como un testigo atento que ha alcanzado la calma y deja hablar en él al mundo.

No encuentro mejor equivalencia de esta emergencia automática de la poesía, contemplada más que elaborada por el poeta, sino en el famosísimo pasaje de la carta de Paul Demeny:

Car JE est un autre. Si le cuivre s'éveille clairon, il n'y a rien de sa faute. Cela m'est évident: j'assiste à l'éclosion de ma pensée: je la regarde, je l'écoute: je lance un coup d'archet: la symphonie fait son remuement dans les profondeurs, ou vient d'un bond sur la scène ${ }^{39}$.

En la paralela carta a Georges Izambard, del 13 de mayo de 1871, Rimbaud se explica: "C'est faux de dire: Je pense. On devrait dire: On me pense"40. Esa misma comprobación la hizo Martí en uno de los poemas que mejor certifican la transición de su poesía, “Cual de incensario roto..." perteneciente a Flores del destierro:

${ }^{39}$ Op. cit., p. 254.

${ }_{40}$ Op. cit., p. 252. 
¿Quién piensa en mí? ¿Quién habla por mis labios cosas que en vano detener intento? $¿$ ¿De dónde vienen los consejos sabios? ¿Adónde va sin rienda el pensamiento? (16-248)

Tratando de comprenderlo en el arte de Emerson, así lo definió: "Él se veía como pupila transparente que lo veía todo, lo reflejaba todo, y solo era pupila" 41 .

La potencia visionaria se articula con esta suerte de impasibilidad creativa, a la que llega en su madurez, y la que de ningún modo puede confundirse con la frialdad parnasiana que reprobó, no porque pecara contra la belleza, sino porque, dice, "le quita lo que el estilo debe tener, el salto del arroyo, el color de las hojas, la majestad de la palma, la lava del volcán" (22-100). Es la serenidad de una visión que surge tras la muerte; entiéndase, desprendida de las contingencias mezquinas del vivir que tantas veces erizan los Versos libres y libre para reconocer la real estructura del universo y sus altas leyes. Del mismo modo que la visión no es producida sino que sobreviene en el imaginario, del mismo modo la poesía irrumpe con fuerza como cosa ajena. El poeta se constituye en el servidor de dos sistemas expresivos que se producen, ambos, fuera del marco de la conciencia, sin que el "yo" parezca rozarlos, reduciéndose a testigo y humilde colaborador.

De ahí se origina la precisión realista, el dibujo nítido y sintético, la tenua melodía, el ritmo elusivo ("desusado" dijo él), los primeros ejercicios del "verso natural", que componen un libro irregular que no ha obtenido la atención que han conquistado otros de Martí, aunque en sus mejores piezas no sea en nada inferior a los Versos sencillos: el libro de las Flores del destierro. "Notas de imágenes tomadas al vuelo" fue la definición del autor en el prólogo que preparó para su edición, que no llegó a hacer, a pesar de reconocer cuánto amaba esos versos. En sus momentos de plenitud ("Cual de incensario roto", "Dos patrias", "Tonos de orquesta", "Señor, aún no ha caído", "Marzo", "Bien: yo respeto", "Siempre que hundo la mente", "Como fiera enjaulada") alcanza esa nota de modernidad que, como señalara de la obra martiana Federico de Onís, va mucho más allá de la inmediata posteridad "modernista": su entonación puede asociarse proféticamente a varios poetas del siglo $\mathrm{XX}$, tal como lo ha hecho Cintio Vitier para los antecedentes vallejianos que surgen repentinamente en Martí, pero percibo que su mayor vínculo es con un poeta estrictamente contemporáneo suyo y que no sé si llegó a conocer: Emily Dickinson. Había muerto en 1896 y aunoue algunos de sus poemas llegaron a aparecer en revistas, la revelación de su obra comenzó con la publicación de

41 Obra literaria, ed. cit., p. 241. 
Poems, en 1890, y Poems: Second series en 1891, cuando ya Martí está en Versos sencillos, en la inminencia de abandonar la poesía por la acción. Tenían comunes devociones emersonianas, comunes impregnaciones de religiosidad natural, comunes atenciones para la vida cotidiana y, desde las Flores del destierro martianas, comunes tendencias a la precisión enunciativa y a la elipsis para dibujar velozmente sus visiones. "Naure, the gentlest mother" es una más sucinta poesía martiana; "The Chariot" una visión metafísica trazada sobre el filo de lo cotidiano que evoca versos sueltos de sus borradores. Ambos coinciden en el deslumbramiento del mes de marzo, que a pesar de sus toques ampulosos, ya obtiene en Martí ese tono de extrañeza: "Marzo fatal sobre la tierra cruza, / marzo envidioso: corta la erizada / a la la nube que al encuentro boga / de Abril, su rival", concluyendo con lírico remate: "Hoy es Marzo, dolor, y Abril mañana" / (16-292). Emily Dickinson trabaja como los pintores ilurninistas de la época, sobre el estilo que llamamos sublime:

Dear March, come in!

How glad I am!

I looked for you before.

Put down your hat-

You must have walked-

How out of breath you are!

Dear March, how are you?

And the rest?

Did you leave Nature well?

Oh March, come right upstairs with me,

I have so much to tell!42

Tal como dijimos del sufrimiento, que en Martí no está dirigido exclusivamente a la formación del Poeta, tal podemos decir de esta disociación de un yo y un otro, que no sólo sirve al trabajo poético. Es un caso parcial de un comportamiento general del espíritu. Martí reconoce un funcionamiento intelectual que está fuera de la fiscalización de la conciencia. Observa así, que "las mejores ideas" no proceden del empecinado trabajo meditativo, sino que surgen "en la conversación de una manera imprevista y espontánea, involuntariamente, pujantemente", lo que provoca la perplejidad del mismo que las formula: "No vienen a remolque de nuestra voluntad, sino que brillan de súbito a nuestros ojos asombrados". En este pasaje, anota que tal comportamiento abarca la órbita completa de la vida espiritual, por lo cual considera que existe en ella una disociación: habría dos fuentes separadas del actuar y del conocer, un "yo" y un "otro". Este último no sólo sabe más sino que registra la existencia

42 Poems (ed. Martha Dickinson Bianchi y Alfred Leete Hampson), Boston, 1937, p. 111. 
de las "leyes" rectoras, muy por encima de lo que puede percibir la subjetividad personal, vista como reducida y escasamente poderosa.

Y esto no es verdad solamente en ideas de orden poético, sino en esfera positiva y experimental. O será que en nuestro interior se está sentado, como guardiản, un consejero íntimo, que por nuestros labios revela a nuestra mente las leyes que han de guiarlo (22-311).

La capacidad para reconocer la macroestructura del universo y las leyes que rigen su funcionamiento, competería a ese "otro" que está compenetrado genética, misteriosamente, de ellas, que es afín al universo. Cuando en su poema de Flores de destierro proclama "De donde vine, ahí voy: al Universo" (16-247) se está refiriendo al "otro" que dentro de él es capaz de esa convergencia de los iguales ${ }^{43}$.

Es apoyo de este entendimiento del aparato psíquico, puede recurrirse a una experiencia personal que consignó en sus papeles privados. Más de una vez Martí se refirió a los pocos momentos de éxtasis que parecieron breves oasis en una vida de sufrimiento, pero este episodio es quizás el más singular porque enlaza con una significación procedente de Emerson:

Ya he andado bastante por la vida, probado sus varios manjares. Pues el placer más grande, el único placer absolutamente puro que hasta hoy he gozado fue el de aquella tarde en que desde mi cuarto medio desnudo vi a la ciudad postrada, y entrevi lo futuro pensando en Emerson. Vida de astros. Por lo menos, claridad de astros (22-323).

\section{En otro apunte aclaró la significación:}

Lo imperfecto de esta existencia se conoce en que en toda ella apenas hay unos cuantos momentos de dicha absoluta, dicha pura, que son los de pleno desinterés, los de confusión del hombre con la naturaleza. (Emerson. La tarde de Emerson: Cuando pierde el hombre el sentido de sí y se trasfunde en el mundo) (21-387).

\footnotetext{
${ }^{43}$ De esta suerte de lenguaje del inconsciente, capaz sin embargo de formularse en estructuras perfectamente organizadas, como son las de la poesía versificada, hay numerosos testimonios en sus anotaciones: "Los versos vienen como empujados desde adentro, y amoldados, dispuestos, encaramados en un taller interior"; "La pluma, como llevada por un duende, rasguea líneas informes, volcánicas, inquietas. Más parece Dios que tiembla que pluma que escribe" (22-235). Contrariamente a una divulgada creencia, poca ayuda presta el freudismo canónico del XX a una interpretación de estos procesos ( $\mathrm{v}$. "El poeta y la fantasía" en Obras completas, Madrid, 1948) siendo más útiles los estudios literarios sobre "la imaginación" (v. "Jalons pour une histoire du concept d'imagination" en J EAN STARobinski, L'oeil vivant II: La relation critique, Paris, 1970) o la percepción de su entronque social (v. Frederic J AMESON, The political unconscious. Narrative as a socially symbolic act, Cornell University Press, 1980).
} 
En esos relámpagos extáticos se desprendía del "yo" personal y toda la conciencia era ocupada por el "otro" que en él hablaba y en ella traducía las leyes fijas del Universo, ya no vistas como verdad emanada de Dios sino como visión objetiva de su funcionamiento.

\section{REALISMO Y OBJETIVIDAD}

En estas operaciones, a consecuencia de sus nuevos imperativos, se esfuma la predicación sobre la realidad, su valoración o enjuiciamiento subjetivos. La sustituye una puntual anotación de los elementos que componen la visión, acentuando los lazos que los relacionan y su energía, estructurante del sentido.

Los Versos sencillos surgen en Castkill Hill como encendidas visiones, después de la compresión espiritual sufrida por el poeta en el Congreso Panamericano de Washington, y en ellos se apaciguan los mecanismos analógicos que en retórica traducen los "como", los "tal parece" e incluso las metáforas, aunque éstas sobreviven tenazmente en las de uso. La descripción del arte poética de Whitman que en este aspecto central hace Martí, puede trasladarse a su propia arte poética en el momento de los Versos sencillos:

Él no esfuerza la comparación y en verdad no compara sino que dice lo que ve o recuerda, con un complemento gráfico e incisivo, y dueño seguro de la impresión de conjunto que se dispone a crear, emplea su arte que oculta por entero, en reproducir los elementos de su cuadro con el mismo desorden con que los observó en la Naturaleza.

Un principio realista rige este arte, fuertemente apoyado en la "reproducción" de elementos naturales, aunque a ellos se llegue verdaderamente a través de la "visión" del "otro" interior e impasible, capaz de percibir la legalidad del universo. En la inminencia de los Versos sencillos Martí a lababa el realismo, tratando de desligarlo de su más notorio rasgo en la vertiente europea de la modernización, que fue el cultivo del feísmo, la mostración del mal, no tanto por considerar que esto no caía dentro de su campo expresivo, sino porque la atención exclusiva para esos aspectos cuestionaba el mismo término literario: "el realismo pleno y verdadero - diceque es útil y encanta, no como el que solo pinta el mal, que es falso".

Todavía cabía otra inculpación al realismo, en la acepción corriente con que se manejaba, en cuanto refería a los métodos estrictamente analíticos que caracterizaron la novela tanto realista como naturalista y que por lo tanto para Martí se emparentaban con las operaciones de la ciencia aplicada a la disgregación de los elementos componentes de una parcela de realidad. La posición equilibradora de Martí y su puesto en el centro del proceso de cambio 
universal, también se traduce en este campo metodológico, pues intenta abrazar las dos tendencias filosóficas opuestas, reintegrar las normas científicas y las aspiraciones de una religión natural, engarzar el idealismo con la precisión que deriva del análisis. En uno de sus apuntes así lo expresa:

No hay más que diferenciar entre los talentos de análisis y los de síntesis. De aquéllos, lo que se llama realismo; de éstos, lo que se llama idealismo. La exageración natural e imponente de una u otra condición es el genio imperfecto: el genio perfecto es el que con el poder supremo de la moderación, co-explica el análisis y la síntesis, sin que ésta prescinda de aquélla, ni niegue aquélla a ésta, y suba a la síntesis por el análisis (22-236).

Como veremos, este mismo problema fue considerado en México por Justo Sierra y por Manuel Gutiérrez Nájera, quienes tropezaron, para su aceptación de la tendencia realista que en prosa o verso literario venía prestigiada desde Europa, con el escollo que les ofrecía su tesonero desdén por los valores morales, por las grandes aspiraciones ideales. Sagazmente Sierra observó que "todos los grandes idealistas han sido realistas, y cuando los realistas no han sido idealistas o estos no han obtenido el sentimiento de la realidad, no han producido obras de artes, éstas han sido incompletas" 44 , superando ya en 1882 la rígida dicotomía que seis años antes había forzado a Gutiérrez Nájera a enarbolar la bandera idealista y proclamar que en México “jamás podrá imperar la escuela realista, hija enfermiza de la prostituida Europa, nacida entre la embriaguez y locura de la orgía" 45 .

La solución equilibradora de Martí le permitía, como a Sierra, recuperar la positividad realista dentro de un arte impregnado de eticidad.

El reconocimiento de la legitimidad de este realismo muestra el largo camino recorrido por Martí desde su tremolante subjetivismo inicial, que aun contamina buena parte de sus Versos libres, pero muestra además el progresivo adentramiento en una lección del arte occidental, desprendiéndose del confesionalismo romántico y ambicionando un registro más preciso y objetivo de las fuerzas que operaban en la realidad, de acuerdo con la pauta proporcionada por la ciencia. Heredero, en este aspecto, de Baudelaire y de Gautier, Rimbaud había estigmatizado el subjetivismo en su carta a George Izambard, proclamando la nueva era de la "poesía objetiva":

\footnotetext{
44 "Literatura francesa", en Justo SirRr A, Obras completas, III: Crítica y artículos literarios (ed. José Luis Martínez), México, 1977, pp. 338-339.

45 "El arte y el materialismo" (1876) en M ANuel Gutiéraz NAjera, Obras, $I$ : Crítica literaria (ed. Ernesto Mejía Sánchez), México, 1959, p. 63.
} 
Sans compter que votre poésie subjective sera toujours horriblement fadasse. Un jour, j'espère, - bien d'autres espèrent la même chose- je verrai dans votre principe la poésie objective, je la verrai plus sincèrement que vous ne le feriez! ${ }^{46}$

La poesía objetiva, que había hecho la catarsis de la estética romántica, al precio de un esteticismo cultista en los parnasianos, comienza a ser capaz de rendir cuentas del mundo circundante del poeta, de la vida y los personajes tenidos por no-poéticos, de la materialidad que impulsaba a la nueva sociedad triunfante, desprendiéndose al mismo tiempo del sentimentalismo, no menos "fadasse", de Coppée.

Ha sido Fina García Marruz quien ha detectado los acentos rimbaudianos en la poesía martiana, y lo ha hechocon relación a los fragmentos de poesía enunciativa y objetiva que sobrevienen en los papeles del cubano como bruscas anotaciones (¿podría decirse iluminaciones?) del tipo de "Versos para los pobres / versos de pobres / fábulas nuevas" (22-30) o las límpidas imágenes que saltan en su prosa, destacándose por la nitidez del dibujo, por la objetividad del registro poético que prescinde de la contaminación subjetivante, por la concentración elíptica que las resuelve en mínimos trazos. En la medida en que imágenes emparentables también se recuperan en los versos de la Dickinson, resulta aún más legítima la observación del crítico acerca de la fuente de donde proceden: "del Norte toma la poesía de lo cotidiano, del hecho desnudo, de la humilde vida diaria" 47.

Desde Flores del destierro la precisión realista y más aún la objetividad, rigen a las imágenes: "la infeliz mujer de Italia / pura como su cielo, que en la esquina / de la casa sin sol donde devoro / mis ansias de belleza vende humilde / piñas dulces y pálidas manzanas" (16-300). O en sus anotaciones, la sequedad con que se hace la evocación de vida pasada: Mi llegada a México / de puerta en puerta / mi chaqué, / la palangana de madera" (21-462). O los dípticos enigmáticos de sus Versos sencillos.

Esta vía del arte había sido la discutida por Justo Sierra al reseñar las dos conferencias dadas en México por el Sr. Lejeune sobre la reciente literatura francesa. El orador había opuesto la escuela idealista (romántica) y la realista (Flaubert y sus descendientes), lo que agudamente Sierra prefirió traducir por las palabras subjetivo y objetivo, reconociendo que "la tendencia exclusivamente objetivista domina en la literatura contemporánea":

${ }^{46}$ Op. cit., p. 252.

47 "La prosa poemática en Martí" en Cintio Vitier-Fina Garcia Marruz, Temas martianos, La Habana, 1969, p. 228. 
La necesidad de buscar el vocablo que represente con mayor exactitud el objeto; de causar con la disposición de la frase, hasta con el sonido de las palabras a veces, una sensación idéntica a la producida por la realidad; el sistema de huir de todo epíteto que acuse una intervención del sentimiento del autor en lo que relata; de suprimir en lo posible, los adjetivos, las ideas generales, todo lo que signifique, lo repetimos, una sustitución del espíritu del escritor a la realidad... ${ }^{48}$

A pesar de la sutil reconversión del problema, y de su reconocimiento de que no había oposición entre idealismo y realismo, Sierra no dejó de reprobar el objetivismo, que percibía como el impersonalismo de la poética de Leconte de Lisle, por considerarlo inadecuado al temperamento imaginativo, ardiente, fuertemente subjetivizado de los hispanoamericanos. Esta discusión habría de reproducirse tal cual ochenta años después con la aparición de la escuela objetalista de la narrativa francesa (Robbe-Grillet) y motivaría nuevamente la alarma de los narradores hispanoamericanos que la habrían de ver, por su presunta frialdad, como una valla a la expresión personal. Justo Sierra procuró tasar equilibradamente las virtudes de ambas tendencias, con tendencia favorable a la segunda:

Las obras subjetivas arrebatan, producen el entusiasmo, que es la forma sensual de la aspiración del hombre a lo desconocido, mientras las obras objetivas hieren las fibras íntimas del corazón, conmueven en el más profundo (sentido) de la palabra ${ }^{49}$.

Viviendo las mismas oscilaciones, también Martí reprobó la "frialdad" parnasiana que le parecía inadecuada al temperamento hispanoamericano, pero aunque era arrastrado por el impulso confesionalista, fue asimilando las virtudes del objetivismo que implicaba un más esforzado trabajo artístico y un mayor respeto hacia el lector, reconocido como entidad adulta capaz de hacer por sí solo la elección del significado, sin que le fuera impuesto explícita y emocionaluiente. Como en otros aspectos de lo que ya era para él una antropología latinoamericana, procuró una solución evolutiva en que sin perder elementos constitutivos del ser americano los enriqueciera con la incorporación progresiva de las tendencias internacionales científicas y técnicas con su organización racional de la vida y trabajo sistemático. En un nivel superior la dicotomía subjetivismo / objetivismo se expresaba por otra: imaginación / razón. En un artículo de La América propugnó la misma solución transculturadora y moderadora: "No hay que rebajar las condiciones que se tienen: sino equilibrarlas por el realce o adquisición de las que no se tienen. Para dar a los pueblos de la América del Sur lo que les

48 Op cit., p. 337.

${ }^{49}$ Op. cit., p. 339. 
falta, no hay que rebanarles la hermosa imaginación, sino levantarla, dotarlos de razón en igual grado" (23-43).

El traslado a una objetiva enunciación de la realidad no sólo respondía a la lección científica que producía un conocimiento verdadero, sino que además permitía reencontrar esa subjetividad y esa imaginación que los hispanoamericanos temían perder en la hora internacional que vivían, gracias a una identificación entre operaciones intelectivas y funcionamiento de la naturaleza. Si se diseñaba objetivamente el funcionamiento del mundo se reproducía la conciencia humana, ya que ambas eran la misma cosa, el mismo orbe natural. Y al cabo de este diseño se conquistaban dos cosas nuevas: se alcanzaba la precisión y la rigurosidad predicadas por la ciencia, y la subjetividad que se reencontraba en esa enunciación objetiva ya no era simplemente la privada, individual, restricta del autor, sino, como pensaba Whitman, la de todos los seres humanos, con prescindencia de su mayor o menor educación, su situación en las jerarquías sociales, sus ideas o creencias. En uno de sus apuntes Martí proclama la universalidad de las leyes naturales:

Aplicad sin miedo a cada acto de la vida las leyes generales de la Naturaleza: en medicina, en desarrollo de pueblos, en la creación del carácter, en medicina de alma. Las leyes de una locomotora son las del cuerpo humano. Las leyes de las mareas son las de los pensamientos. Y las leyes que rigen la existencia de un pueblo, son las mismas que rigen la vida de una flor. Pues, ¿de dónde viene su admirada sabiduría a las gentes de campo y de mar? $(22-324)^{50}$.

El objetivismo concluía siendo consecuencia de una estética que se había fundado respondiendo al desafío de la ciencia, en el ápice de la modernización. La preocupación de Martí, de Sierra, la reencontramos en Manuel González Prada. Gracias a su maciza cultura universal, el peruano buscó su fuente en las letras alemanas. Como Martí, admiró la revolución poética aportada por los “suspirillos germánicos" becquerianos y como Martí, detestó a los blandos y quejumbrosos imitadores, preguntándose: “¿Por qué los germanistas castellanos no aclimatan en su idioma el objetivismo alemán?" Y aunque no le complacía la "frialdad marmórea" de Goethe reconocía que "en sus versos parece realizar lo imposible: como una

50 Este razonamiento llevó a Martí a afirmar la existencia de "hechos del espíritu", equivalentes a los "hechos científicos" y por lo tanto a concluir: "Asombran las correspondencias y relaciones entre el mundo meramente natural y extrahumano y las cosas del espíritu del hombre, tanto que un axioma científico viene a ser una forma eminentemente gráfica y poética de un axioma de la vida humana" (22-141). El ejemplo que proporciona como prueba, tomado de una conferencia de Charles Dana, está lejos de corroborar su aserto y más bien revela la libertad del asociacionismo analógicomartiano. 
arquitectura en movimiento, como una música petrificada, como una pintura con palabras"'5l.

En la inminencia de los Versos sencillos Martí hace suya la eventualidad de una "poesía objetiva" tal como la que Rimbaud aconsejaba a Izambard, la cual, como Rimbaud en su carta a Demeny insiste, reclamaba una estricta investigación de los mecanismos expresivos, en primer término la lengua de la poesía: "Trouver une langue; du reste, toute parole étant idée, le temps d'un langage universel viendra.(...) Cette langue sera l'âme pour l'âme, résumant tout, parfums, sons, couleurs, de la pensée accrochant la pensée et tirant" 52 . La misma obsesión, en casi los mismos términos, la reencontramos en González Prada y en Martí, pues para ambos la clave está en esta reconstrucción de una lengua adaptada a la poesía, en estrecha asociación con el pensamiento, pues para ellos palabra es idea. Una selección de apuntes de Martí, entre sus papeles sueltos, expresa la misma concepción rimbaudiana:

Sin una sola palabra más de las que necesita, ni dos imágenes por una, ni una imagen donde no concurra a la claridad de la idea (22-100).

Adoro la sencillez, pero no la que proviene de limitar mis ideas a este o aquel círculo o escuela, sino la de decir lo que veo, siento o medito, con el menor número de palabras posibles, de palabras poderosas, gráficas, enérgicas y armoniosas (22-101). Hacer llorar, sollozar, increpar, castigar, crujir la lengua, domada por el pensamiento, como la silla cuando la monta el jinete; eso entiendo yo por escribir (22-102).

Para mí las palabras han de tener a la vez, en saludable, sin exceso de ninguna de las tres, sentido, música y color (22-102).

Que se trataba de una adquisición de su estética, a la que había llegado por un ingente esfuerzo de asepsia, separando las voces de los ecos a la manera machadiana y buscando el ajuste entre su concepción del mundo y la escritura poética, queda patentizado en el comentario que en sus fragmentos sigue a la última anotación reproducida más arriba, el cual dice:

En el esfuerzo por obtener este estilo, que unos dicen que he logrado, me aparté sin duda mucho de lo corriente, como el que toma impulso para saltar, y estas cualidades, que con la edad y el cultivo han llegado, a juicio de algunos, al reposo, fueron, al aparecer, excesivas y violentas tanto que no escribiría hoy, por cierto, con la que escribía, con menos literatura, menos vida, hace cinco años (22-102).

Efectivamente, largo tiempo y larga meditación dedicó Martí a la lengua, revisando diversos tópicos: los arcaísmos, los neologis-

${ }^{51}$ Op. cit., p. 12.

${ }^{52}$ Op. cit., pp. 255-256. 
mos, los extranjerismos, los regionalismos y dialectalismos americanos que fue coleccionando en sus libretas, los significados múltiples, etc. El centro de esta investigación fue la búsqueda de valores fijos e inamovibles, especialmente difíciles en época de transición y abrupta renovación. El propósito, el mismo que orientó a Darío: la fundación de una lengua americana de la poesía que se ajustara al coloquialismo del habla y a la elegancia culta. Martí y Darío vieron facilitada esta tarea por sus desplazamientos entre las diversas áreas lingüísticas americanas; si Martí no convivió con la zona sureña platense donde se había producido la más drástica renovación, suplió esta carencia con un persistente escudriñamiento de las invenciones lexicales de la zona, los desplazamientos semánticos, las articulaciones sintácticas, la invasión de galicismos que en ocasiones reprobó, la incorporación de indigenismos, materiales de que están plagados algunos de sus Cuadernos de Apuntes y sobre los cuales se manifestó positivamente comentando un libro de Juan A. Piaggio ${ }^{53}$. Fuera de su conocimiento personal de Centroamérica, México y Venezuela, amén de su Cuba natal, desde su mirador neoyorkino dispuso de una información amplísima sobre la totalidad hispanoamericana, la que puso al servicio de esa nueva lengua limpia, flexible y vivaz, huyendo tanto de la "jerga arcaica” como de la "jerga científica".

Como en el título lezamiano, "la fijeza" motiva su búsqueda, puesta a su vez al servicio del rigor y de la precisión, pues el ajuste lexical de la poesía implicaba el mismo ajuste exacto de la idea. Su pesquisa de lo permanente lo acercó a una estimación etimológica, semejante a la que practicó Unamuno, que veía como la única capaz de resistir el desgaste del uso: "Han de usarse laś palabras como se ven en lo hondo, en su significación real, etimológica y primitiva, que es la única robusta, que asegura duración a la idea expresándola en ella" (21-164). Y en la medida en que un léxico sólo funciona dentro de una sintaxis, afirmó el raigal sistema lingüístico español aunque desembarazándolo de arcaísmos y aceptando las incorporaciones de otras lenguas:

Lenguaje que del propio materno reciba el molde, y de las lenguas que hoy influyen en la América soporte el necesario influjo, con antejuicio suficiente para grabar lo que ha de quedar fijo en esta época de génesis, y desdeñar lo que en ella se anda usando, lo que no tiene condiciones de fijeza, ni se acomoda a la índole esencial de nuestra lengua madre.

Coincidió con González Prada en la oposición frontal al arcaísmo, a la restauración de formas caídas en desuso, abogando por la nitidez de una lengua firme y diestra que transpusiera el habla

53 "Tipos y costumbres bonaerenses", en Obra literaria, ed. cit., pp. 225-229. 
de su tiempo. Esa lengua era condición previa de la obtención de una objetividad que acreditaba la vía epistemológica de la poesía, aunque Martí no podía menos de ser consciente de que la austeridad que exigía de la poesía reducía notoriamente su campo expresivo. Se trataba de una higiene de las letras, lograda por el camino del laconismo, la precisión, el rigor cognoscitivo, el retaceo de la efusión subjetivista, la prescindencia del discurso doctrinal, aunque ese camino también debía evitar la frialdad negadora de la emoción y el mero cientificismo que la hubiera apartado de su propósito último: ser el canto de todos.

Creo que fue la conciencia de esta reducción de posibilidades expresivas, cuando estaba abogando por un férreo ajuste de palabra e idea, lo que motivó su apelación a las matrices métricas tradicionales, a los sistemas rítmicos y a las estructuras melódicas, a los que había sido anteriormente esquivo. No sólo restauraban ese equilibrio moderador entre una larga tradición recibida y un presente cargado de futuridad, sino que proporcionaban un enorme campo complementario a las necesidades expresivas, permitiendo que la emoción, el subjetivismo, corrieran por las pautas sonoras, reforzando, prolongando, contradiciendo a veces, lo que las precisas palabras decían. Estas palabras se desdoblaron en sus significantes y significados construyendo dos tejidos paralelos, acordes o discordes, que-deplegaban lo que Darío habría de llamar dos melodías: "Como cada palabra tiene un alma, hay en cada verso, además de la harmonía verbal, una melodía ideal". Esa función de los sonidos carecía del código escrito que en los significados permitía apelar a los rigores etimológicos para alcanzar la fijeza, pero no por eso dejaba de existir tal código, que se reencontraba viviente en el habla de los hombres americanos. Constituía un misterioso depósito que aunque no pasara por la conciencia, no dejaba de herir agudamente la sensibilidad. A esta altura de su evolución intelectual, Martí, que había descubierto el "otro" que hablaba imperiosamente dentro de sí con más profunda verdad que su yo subjetivo, también había registrado la distinción entre oir y escuchar (la que va entre ver y mirar) que permitía que el receptor del mensaje podía oirlo aunque no lo escuchara, lo que dice, en "Cual de incensario roto", el poema en que hahía percibido al "otro" que hablaba dentro de él: "Que todos oyen cuando nadie escucha”. Ésta era la vía sensible y no intelectiva, la que por lo tanto respondía a los componentes sensibles, sonoros, de la ooesía y no a los intelectuales, significativos. A ella aludió con precisión en el orólogo de Versos sencillos al señalar que repetía "un consonante de propósito, o los gradúo y agrupo de modo que vayan por la vista y el oído al sentimiento" (16-22). E1 ojo que lee, el oído que registra el sonido, son las vías para recihir, en el sentimiento, el efecto de los consonantes dentro del gran tejido fónico. 
Llegados a este entendimiento maduro de la poesía, tanto Rimbaud como Martí, antes de abandonarla por la acción tal como quedaba previsto en esta vía revolucionaria, entonaron una poesía armónica y reconciliada. A la plenitud de "O saisons, ó chàteaux, / quelle âme est sans défauts?" responde el saber austero, objetivo, de la pura melodía:

Yo he puesto la mano osada, de horror y júbilo yerta,

sobre la estrella apagada

que cayó frente a mi puerta.

University of Maryland.

ÁNGEL RAMA 